https://helda.helsinki.fi

\title{
On the Historicity of Social Ontology
}

\section{Patomäki, Heikki}

2020-12

Patomäki , H 2020 , ' On the Historicity of Social Ontology ', Journal for the Theory of Social Behaviour, vol. 50 , no. 4 , pp. 439-461 . https://doi.org/10.1111/jtsb.12254

http://hdl.handle.net/10138/322673

https://doi.org/10.1111/jtsb.12254

acceptedVersion

Downloaded from Helda, University of Helsinki institutional repository.

This is an electronic reprint of the original article.

This reprint may differ from the original in pagination and typographic detail.

Please cite the original version. 


\title{
On the Historicity of Social Ontology
}

A next-to-final version of Patomäki H. "On the historicity of social ontology". J Theory Soc Behav. 2020; 1-23. https://doi.org/10.1111/jtsb.12254. This version includes the appendix that is permanently stored at https://zenodo.org/record/3984609\#.X0yFqHtS8aH.

\author{
Heikki Patomäki \\ Professor of World Politics and Global Political Economy \\ Faculty of Social Sciences \\ P.O. Box 54 (Street address: Unioninkatu 37) \\ 00014 University of Helsinki, Finland \\ tel. +358 - (0) $40-5184854$ (mobile) \\ E-mail: heikki.patomaki@helsinki.fi \\ https://www.helsinki.fi/en/university/people-finder/heikki-patomaki-9075585 \\ http://patomaki.fi/en/
}

\begin{abstract}
The question I raise is whether the basic features of mind, social categories, and society are unchanging or changing. Some understandings of ontology would seem to suggest that social ontology is a branch of metaphysics. However, as the history of concepts such as metaphysical and ontology indicate, our concepts and knowledge are historical. It is widely held that society is conceptand activity-dependent. I examine critically two strands of social ontology in terms of their answers to this problematic: (1) John Searle's theory of the construction of social reality and (2) critical realist theory of mind and society as interlaced emergent layers of reality. Apart from emergence in natural systems, there is also emergence beyond nature as consciousness, agency and society cannot be completely explained in terms of biological realities; but how and when did this emergence occur? We need an account of the emergent order of language, reflectively conscious mind, and institutions not only for its own sake, but also because the process whereby new objects and properties emerge may be on-going, path-dependent, diverse, and open-ended. The main argument is that the object of study of social theorists is geo-historically specific, liable to diversity within any given worldhistorical epoch, and open to further changes and new forms of emergence in the future.
\end{abstract}

\section{Keywords}

emergence, future, metaphor, Searle, stage, Whig-history 


\title{
On the Historicity of Social Ontology*
}

\author{
$\underline{\text { Introduction }}$
}

Words and concepts, such as "metaphysics" and "ontology", are historical. They emerge, evolve, branch, change, and sometimes disappear. We know metaphysics from Aristotle's Metaphysics, although Aristotle himself did not know the word. A century or more after Aristotle's death, an editor of his works titled those fourteen books Ta meta ta phusika - "the ones after the physical ones" - the 'physical ones' being the books contained in what we now call Aristotle's Physics, probably referring to a suggested reading order. The suggested reading order was in turn based on the idea that Physics focusses on how things in nature change, whereas Metaphysics is about the fundamental things (especially essences) that do not change. Only the first causes, or being as such, would be unchanging in the Aristotelian worldview, whereas in nature things are changing. (Politis, 2004, pp. -4, 19-21, 51)

The Aristotelean meaning of metaphysics prevailed in Europe until the modern scientific revolutions in the $16^{\text {th }}$ and $17^{\text {th }}$ centuries. At the time when the meaning of 'cause' changed, metaphysics started including various philosophical questions that could not be otherwise classified (mind-body, freedom of will and so forth). It became almost a residual category of philosophy. This was when the term 'ontology' - the study of being - arose. At first it was used as a synonym of metaphysics (compare Lawson, 2019, p. $21 \mathrm{fn} \mathrm{1).} \mathrm{The} \mathrm{two} \mathrm{terms} \mathrm{remain} \mathrm{interwoven,} \mathrm{but} \mathrm{further}$ changes in the scientific understandings of the world have contributed to their partial differentiation. After pragmatically successful breakthroughs in physics, chemistry, biology, and medicine from Newton to Maxwell and from Jenner to Darwin, the debate between the nominalists and the realists took on new meanings. Especially since the 19th century, nominalists have been allied with modern day empiricists, who tend to treat scientific theories instrumentally and deny the relevance of ontology (theories are just tools indicating means to achieve ends); whereas realists have not only fixed their eyes on the realisticness of scientific theories but also favoured explicit ontology. (Patomäki, 2020)

If our concepts and knowledge are historical (as the history of concepts such as metaphysical and ontology indicate) and if society is dependent on concepts and knowledge, it would seem to follow that society must be changing, possibly also in terms of its essential or fundamental properties and powers. The question I want to raise in this paper is indeed whether the basic features of mind, social categories, and society are unchanging or changing. If the former, they must be eternal or timeless, like the first causes in Aristotelean metaphysics; or at least fixed and enduring over the relevant period of time (for example for the entire duration of the species). If the latter, social ontology cannot be separated from historical social sciences or concrete, empirical, and historical research, or from futures studies anticipating and exploring possible future societies (in the

\footnotetext{
* This paper would not exist without the Cambridge Social Ontology Group (CSOG). 'This motley collection gets together at various times and places, including a regular meeting for two hours every Tuesday morning, in term time and beyond, year after year, to discuss matters of social ontology, just for the pleasure of so doing.' (Lawson, 2019, xiii). I participated in these meeting during the winter, spring and early summer of 2019, when I was a visiting fellow at Clare Hall. During those sessions, Yannick Slade-Caffarel suggested that I participate in the $6^{\text {th }}$ Biennial Social Ontology Conference in August 22-24, 2019, at the Tampere University, for which this paper was originally written. In 2019, CSOG discussions revolved around Tony Lawson's new book The Nature of Social Reality: Issues in Social Ontology. With his own very clearly articulated ideas about emergence and history, Lawson has provided a most fruitful counterpoint for thinking about the historical "nature" of mind and society. I am thankful for very helpful comments to the participants of the "Ontological aspects of critical social theory" panel of the Tampere conference on 24 August 2019, chaired by Rachel Cooper; to Tuomas Forsberg and Jamie Morgan; and to two anonymous reviewers.
} 
processual view, the present consists of on-going processes, which include some relatively enduring but temporary things, structures and mechanisms).

I examine two strands of realist social ontology in terms of their answers to these questions: (1) John Searle's $(1995,2010)$ theory of the construction of social reality and (2) critical realist theory of mind and society as interlaced emergent layers of reality (for example Archer, 1995, 2000; Bhaskar, 2008a, 1998, 2008b; Lawson, 1997, 2019). Novel questions arise, as both imply (i) the geohistorical emergence of complex society (involving institutions, activity- and concept-dependent structures and so forth) and (ii) possibility of developments within the emergent layer of complexity (new institutions, actions and structures are likely). When exactly did complex society emerge? Why did this emergence happen (and what exactly happened then)? What explains the further evolvement of society and to what extent does this evolvement necessarily affect theories of social ontology? A key theme is that social ontology has so far focussed on contemporary liberaldemocratic capitalist societies, while it could be more reasonable to conceive social ontology in systematically historical and processual terms (see Rescher, 1996; compare Little, 2016, chap. 1).

This leads to the question whether it is possible to theorise historical developments in terms of stages, somewhat in a manner of the theories of classical political economy or contemporary theories of moral learning? Stages do not have to mean, however, that that each stage represents a type of society from a closed list of possible frameworks (such as feudalism, capitalism and socialism) or that stages must follow each other in a necessitarian order (for a critique of social theories based on closed lists and necessary sequences, see Unger, 1997, pp. 33-41). Claims about stages can be seen as hypotheses concerning some aspects of contingent past developments in an open-ended process of world history, where future stages can be anticipated but not predicted.

The first section focusses on Searle's theory and his account of the emergence of language and development of institutions, identifying some critical ambiguities in both. In the second section, I consider critical realism and its central claim that new structures and layers can emerge over time. Apart from emergence in nature, there is also emergence beyond nature, namely to the level of culture. By cultural I mean transmission of skills and knowledge by means of communication and learning rather than through genetic or epigenetic changes. Like all emergent layers of reality, culture remains dependent on earlier and lower layers. The question is how and when did this emergence occur? We need an account of the emergent order of language, reflectively conscious mind, and institutions not only for its own sake, but also because the process whereby new objects and properties emerge may be on-going, path-dependent, diverse, and open-ended. In other words, the object of study of social ontologists may be geo-historically specific, liable to diversity within any given world-historical epoch and open to further changes and new forms of emergence in the future. I go on to propose a simplified scheme of how language, practical skills, group-size and complexity are connected and offer a simple illustration of how change and emergence affect also the basic categories of social ontology. This illustration concerns the vast distance between the minds of Intermediate Bronze Age world of Mesopotamia and our contemporary global world. In the conclusion I return to the question of stages and discuss types of geohistorical change.

\section{$\underline{\text { Institutions in Searle's theory }}$}

Searle's The Construction of Social Reality (1995; abbreviated here as CSR) is perhaps the most widely known work in social ontology. In chapter 2, Searle (1995, pp. 31-57) distinguishes between brute, social, and institutional facts. Brute facts are independent of social activities or institutions (for example "the sun is ninety-three million miles from the earth"). Social facts are not 
confined to the world of humans. Cooperation is evolutionarily beneficial and many animals are capable of social acts. However, institutional facts are qualitatively different from mere social facts. "Congress passing legislation is an institutional fact; hyenas hunting a lion is not" (1995, p. 38). Institutional facts involve constitutive rules ( $\mathrm{X}$ counts as $\mathrm{Y}$ in context $\mathrm{C}$ ), self-referential concepts, and performative utterances. These in turn require complex language, which must have emerged first, before institutional facts became possible. Furthermore, Searle maintains that in the world of institutional facts, processes are always prior to product. Objects such as a government, a dollar bill or a contract are contingent products of on-going processes; they are "the continuous possibility of the activity" (1995, p. 36).

If language is a pre-condition for the emergence of institutional facts ("the linguistic forms in question are partly constitutive of the facts" (1995, p. 37)), then social ontology should include an account of the emergence and development of language. At one point Searle (1995, p. 128) refers to Noam Chomsky's account of Universal Grammar, but does not take a stand on whether Chomsky's account of language is correct. In his reply to Barry Smith, Searle seems to be arguing that biological evolution has generated both collective intentionality and language (Smith and Searle, 2003, p. 304). At another point of CSR he states, however, that language is one of human institutions (1995, p. 27). Chapter 3 of CSR is devoted to language and reality. Here Searle hints at the historical development of language, also to avoid circular argumentation about language as an institution and as something that is constitutive of institutions. "[T]o have institutional facts at all, a society must have [first] at least a primitive form of a language..." (1995, p. 60). This seems to imply stages of development. Searle distinguishes between pre-linguistic intentional states such as feeling hungry; a language-like system of representation or primitive language; and full-blown natural languages such as English, French or German (comprising infinite generative capacity, the presence of illocutionary force indicating devices, quantifiers and logical connectives and so forth) ${ }^{1}$. However, Searle does not use these distinctions to say anything about the real historical development of language, but only to explicate the sufficient conditions for a fact to be languagedependent.

In chapters 4 and 5 of Making the Social World, Searle (2010) has more to say about the role and development of language. Here he discusses prelinguistic humans, not as a mere thought experiment but as a real historical phase. These early humans had biological forms of intentionality (in the same way as hyenas or apes might do) but lacked language. In these two chapters, Searle does two things. On the one hand, Searle tries to show that language is different from other kinds of institutions (language does not have powers that go beyond meaning unlike other institutions and so forth.). On the other hand, he gives a "logical" account of the steps required to enable speech acts to carry a deontology of rights, duties, commitments, and so forth, and to thereby enable status function declarations and institutions ("I am speaking of logical components; I have no idea what the actual history was"; Searle, 2010, p. 76). Searle implies that there must have been intermediate historical steps from prelinguistic consciousness to our contemporary world, but what he provides is a rational reconstruction of an apparently one-off (even if slow) transition toward the current human civilization (as exemplified by the present-day US). The process must have been completed by the time of the emergence of institutional facts, whenever that may have happened. Searle leaves open the possibility that full-blown natural languages have existed as long as our species homo sapiens (prelinguistic humans would then consist of other hominini species; here Searle cites Hauser, Chomsky and Fitch, 2002, who discuss the evolution of language only in biological terms).

The institutions Searle analyses in CSR are characteristic of a modern $20^{\text {th }} / 21^{\text {st }}$ century liberaldemocratic capitalist society, such as money, property, marriage, governments, universities, elections, football games, cocktail parties, and law courts. Each of these institutional forms have 
evolved historically; and in each case the specific form that Searle considers are drawn from the US. Money is dollars; parliament is Congress; law is US law; football is American football, and so forth (for a critique of cultural imperialism that rests on the power to universalize geohistorical particularisms by causing them to be misrecognized as such, see Bourdieu \& Wacquant, 1999).

Institutions such as marriage, property, or money "create [...] forms of powers, rights, obligations, duties, and so forth., and it is characteristic of such phenomena that they create reasons for action that are independent of what you or I or anyone else is otherwise inclined to do" (Searle, 1995, p. 70). There is also a much longer list of deontic phenomena: rights, responsibilities, obligations, duties, privileges, entitlements, penalties, certifications, qualifications, authorizations, and permissions (p. 100). Searle distinguishes between the initial creation and continued existence of an institutional fact but considers mostly singular facts (p. 115), not the creation and continued or discontinued existence of the institutions per se. Searle is mainly interested in outlining the logical structure of institutional reality rather than in the conceptual and institutional history of deontic phenomena such as rights and obligations. He provides two examples from political history: the American declaration of independence from 1776, where "the Founding Fathers" created something by acting as if an institution existed and, more generically, revolutions (such as the 1917 Russian revolution) where all or most members of a society refuse to acknowledge property rights (pp. 1179).

Searle's discussion on the development of money indicates, however, that he acknowledges longterm evolvement of institutions (at one point he writes that "the creation of institutional facts is typically a matter of natural evolution", p. 125). In his history of money, Searle relies on a stylised neoclassical theory, but claims that his account is not dependent "on its historical accuracy" (p. 42). The use of commodity money (for example gold) is in effect a form of barter. Late medieval practice of issuing paper certificates to the depositors was a step toward full fiat money. "A stroke of genius occurred when somebody figured out that we can increase the supply of money simply by issuing more certificates than we have gold" (p. 43). The next thing was to forget the gold and have certificates only. The moral of this history is clear: only in the $20^{\text {th }}$ century did money become fully socially constructed (US dollar remained convertible to gold until 1971 when President Nixon unilaterally disconnected the two). Anyone now going to a bank, or to the central bank, to claim his dollars' worth against notes would simply get another note in return; nothing tangible remains behind the convention and tacit declaration that $\mathrm{X}$ counts as money in context $\mathrm{C}$.

In CSR Searle does not mention the term emergence, but discusses it in his other works (especially in Searle, 1992). According to Tony Lawson (2019, pp. 34, 199-202), Searle's position is ambiguous. Oftentimes Searle presupposes that the organisation of the components matter and the organisation of the whole is by definition irreducible to its parts. Although Searle's starting point is that new realities can emerge, he nonetheless assumes that these new realities can be reduced causally and ontologically to the components existing at a lower level of reality. Only consciousness is ontologically irreducible, but it too is causally reducible. Searle's somewhat ambiguous reductionism may explain his commitment to methodological individualism (or perhaps vice versa?), but even his individualism tends to be confusing. For instance, Searle (2010, p. 62) criticises the social contract theorists for assuming that language-speaking creatures could exist in a state of nature: "Once you have a shared language you already [...] have a society".

Language is not only constitutive of institutional realities, but - also on the basis of Searle's own analysis - language changes the kinds of beings humans are. Nonetheless, in Searle's overall system it is possible to imagine that society is reducible to language-speaking individuals and that fullblown language is something that the human species homo sapiens has always had. The timeless 
"logical" analysis of the evolvement of capacities making society possible helps to sustain this presumption. This timelessness then facilitates the tendencies (i) to universalize particular geohistorical experiences and (ii) tell Whig-histories about the modern world (see for example the discussion of property rights in the US and collapse of the Soviet Union in Searle, 1995, pp. 90-4).

To complicate things further, in chapter 6 of CSR Searle discusses the idea of the Background, which he says is similar to Pierre Bourdieu's habitus ("Pierre Bourdieu's important work on the 'habitus' is about the same sort of phenomena that I call the Background", p. 132). The Background enables linguistic and perceptual interpretation, structures consciousness, generates motivational dispositions, enables the narrative or dramatic form of our experiences, facilitates certain kinds of readiness, and disposes us to certain sorts of behaviour. The Background is meant to explain how it is possible that people are following rules without being conscious about following such rules. This explanation may well be sound, but what is interesting from the point of view of the historicity of social ontology is that the background competencies, motivations, dispositions and so forth. would seem to be geo-historically specific and not universal. The existence of the Background may be common to all language-speaking humans in a society, but its contents would seem to be as contextspecific as Searle's late $20^{\text {th }}$ century US-based examples indicate. Searle does not draw conclusions in terms of temporal or spatial differences from this aspect of the Background.

\section{$\underline{\text { Emergence in critical realism }}$}

Although critical scientific realism (CR) is often associated with the works of Roy Bhaskar, it has been a collective endeavour involving several UK-based prime movers such as Margaret Archer, Dave Elder-Vass, Bob Jessop, Tony Lawson and Andrew Sayer (here I focus on Bhaskar, Archer and Lawson; for an overview, see Patomäki, 2019). The key ideas of CR can be understood with the help of three philosophical theses: ontological realism, epistemological relativism and judgmental rationalism. Here I focus on the first one. Ontological realism means, among other things, that the real world must be differentiated, structured, layered, open-systemic, and possess causal powers for science and many other practices to be intelligible. All systems are open, but at the level of society also artificial closure is impossible. New structures and layers emerge. Society is an emergent layer which is, in part, qualitatively distinct from natural systems. Social actors possess real causal powers shaping also lower-level realities (for example, the effect of $20^{\text {th }}$ century nuclear tests on rocks and metals, which future generations will be able to measure at least for millennia).

New relations and things may emerge; a new combination and organisation of elements may result in new properties and powers at the level of the whole. British emergentists developed these ideas already in the late- $19^{\text {th }}$ and early-20 ${ }^{\text {th }}$ centuries (O'Connor \& Wong, 2015). Perhaps the first emergentist was John Stuart Mill (1882, pp. 459-60), who argued that the "phenomena of life, which result from the juxtaposition of [inorganic] parts in a certain manner, bear no analogy to any of the effects which would be produced by the action of the component substances considered as mere physical agents". In Realist Theory of Science, Bhaskar (2008, pp. 102-3) basically adopts Mill's argument and explicates it a bit further. The key point here, however, is that apart from emergence in nature, according to Bhaskar and CR more generally, there is also emergence beyond nature. $^{2}$

As discussed in The Possibility of Naturalism (Bhaskar, 1998, especially pp. 41-8), the emergent layer of society concerns the level of intentional action and society. Bhaskar argues that while the pre-existence of social forms are a necessary condition for any intentional act, reasons for actions can and must be causes. However, that presupposes specific powers of the mind. The causal powers 
of mind are explained in terms of "synchronic emergent powers materialism". The brain provides a basis, medium and vehicle of mental powers, but the powers of the human mind are not reducible to the brain. As the higher-order principles of the mind cannot be completely explained in terms of lower-order ones of the brain, the former can have a logic of development of their own, within the constraints and possibilities of the brain and body more generally. (Bhaskar, 1998, pp. 106-19) The properties and powers of the mind evolve in social contexts; and psychological states are relational and make references to social states and structures. As higher levels can be causally efficacious with regard to lower levels, the mind evolving in social contexts can in turn shape the structures of the brain and body (in addition to shaping other life-forms, ecosystems, landscapes and so forth). It is important to stress that social contexts and structures exist in a different way than natural structures and mechanisms. Social structures are activity- and concept-dependent and are thus usually much less stable and enduring than natural structures. The powers and tendencies generated by social structures are not invariant across time and space. Change is ubiquitous.

Typically, critical realists argue that not everything is socially constructed. Emergence beyond nature remains limited and partial. The ontic layers of mind and society must operate on biological materials that precede the emergence society (and thus institutions in Searle's terms), while society is not reducible ontologically or causally to its components. "Certainly historical pressures can modify the most basic bodily needs, as in different cultural shapings of how we eat and sleep, but these have to work within the confines of the fact that we must eat and sleep" (Archer, 2000, p. 41). Moreover, the effects of the embodied mind and complex society are not reducible to language. For example, inflation affects negatively the buying power of those with fixed incomes, "whether or not they are aware of the cause, and regardless of how they define it" (p. 42). Humanity is an emergent property of our species. Humanity evolved through practical action in the world, and it is this that has made complex society possible. Discursive knowledge concerning subject-subject relations adds to our human and social possibilities, but body-environment and subject-object relations are, in some sense, primary, although we can now monitor, displace, and reorder priorities (p. 200).

In a similar manner, Lawson argues against Searle's exclusive focus on language: community formation necessarily precedes the development of language and therefore non-linguistic social structure formation must be possible (see Lawson, 2016a, 2016b; and Searle, 2016). Or more precisely, Lawson (2016a, p. 360) writes that "whilst Searle puts his primary emphasis on language as a foundational feature of social reality, I additionally emphasise the organising role of emergent collective practices in sustaining (equally emergent) social totalities". For Lawson, collective practice - even if presupposing intentionality and forms of representation - does not require developed language. We remember Searle's related point that social facts are not confined to the world of humans. Cooperation is evolutionarily beneficial and many animals, including hominins not possessing language, are capable of social acts. Lawson follows Searle in distinguishing between different phases of development of language, but then reverses Searle's argument about the primacy of language by suggesting that the emergence of language likely required, as a precondition, prior existence of deontology-carrying collective practices. Lawson explains:

[I]t is difficult to imagine both how language could emerge outside of a community, and also how the sort of coordination required for any kind of community life in general, as well as for the emergence of language in particular, could be feasible and survive without deontology-carrying collective practices of some sort. In particular, it is very likely the case that a necessary precondition for the emergence of any fully developed language is the prior practice of using simple symbols including sounds in communication. These would have signalled basics like danger, or food, and so forth. The point, though, is that in order that these function in the sense of communicating the intended meaning of the utterer, specific 
sounds would need regularly to be associated with the same referent (like 'danger'), with an effective obligation accepted by those involved not to vary the association. But it is difficult to see how this sort of relatively complex form of cooperative practice of associating symbols with features of reality in a collective manner could develop outside of small communities already coordinated by, and familiar with, rather simpler forms of (emergent) collective practice. (Lawson, 2016a, p. 375)

The difference between Lawson and Searle is relatively minor. Both agree that there must have been intermediate historical steps from prelinguistic consciousness to the world of full-blown languages, "founding fathers", complex legal systems and elaborate institutions such as money. Like Searle, Lawson (2016a, p. 377) admits that he has no idea about "how matters actually evolved" and relies on thought-experiments. What seems slightly confusing, however, is his idea that while complex contemporary forms of institutional reality involve a deontology that requires language as a necessary condition, this reality "is in part linguistic but not linguistically constituted". A possible and plausible interpretation is that what Lawson means is closely related to Archer's claims, namely that our mind is embodied and complex society and its effects are not reducible to language. The idea is to stress the importance of practical actions and orders, in contrast to mere conversations, declarations and linguistic constitutions. These are reasonable points. The problem lies in the confusion about the process whereby pre-existing elements become (with some modifications) relationally organised to constitute components of a novel system. This process, as described by Lawson and Searle, can be schematically described as in Figure 1.

Figure 1: A schematic version of Lawson's and Searle's story of world-historical developments

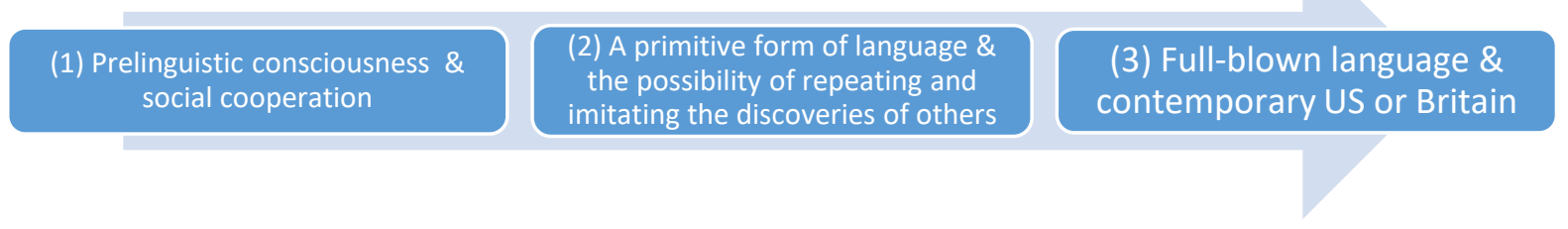

This scheme may not be categorically wrong, but as an account of the emergence of mind and society it is too simple and potentially misleading, as it risks implying a Whiggish story of the world-historical developments from pre-history to the contemporary Anglo-American world. In the case of Searle, this storyline seems quite clear, although he might counter that outlining an abstraction as condition of possibility is neither Whiggish nor not. The problem is that this counter would reinstate a rather categorical split between real history and philosophical social ontology, while almost all Searle's examples concern specific geohistorical contexts, mostly contemporary US, an occasional reference to the Russian revolution notwithstanding. Critical realists use fewer illustrations than Searle (many of Lawson's examples concern everyday life in the beautiful university town of Cambridge) and thus the context is not indicated as clearly. There are nonetheless many senses in which the post-1960s Britain forms the explicit context of the original development of CR social ontology. For example, in the 1989 postscript to The Possibility of Naturalism, Bhaskar (2005, p. 190) stresses that discussions around generic concepts such as society, social structure, human needs, ideology and emancipation are at the heart of the British debates around Thatcherism, welfare state, and the nature of socialism ("that take place at precisely this level of abstraction"). The context of development of ideas and their potential domains of application are different, but the two may be much more tightly interwoven than what is usually 
acknowledged even among the critical realists. The social theorist should be able to imagine and study radically different contexts, rather than being content on drawing primarily from the experiences of those particular contemporary contexts where they happen to reside.

On the emergence and development of language, mind and society

I agree with Lawson $(2019$, p. 41) that "a significant task facing any science is to provide detailed empirically informed accounts of how, in different domains, relatively stable organisations of lower level phenomena do arise or have arisen". It is important to have a historical causal account of the emergent order involving language, reflectively conscious mind and institutions not only for its own sake, but also because the process whereby new objects and properties emerge may be on-going, path-dependent, diverse, and open-ended. Social ontology can neither pretend to be outside real time and history nor to be based merely on particular geohistorical experiences.

The problem is that there is no scientific consensus about the development of language, mind, and complex society in their various manifestations. What seems uncontroversial is the existence of some biological capacity of humans that allows us (and not, for example, dogs or chimpanzees) to readily master any human language without explicit instruction Hauser, Chomsky \& Fitch, 2002, p. 1571). The oldest known skeleton of an anatomically modern Homo sapiens dates to about 200,000 years ago. At the same time, it is widely agreed in archaeological and anthropological literature that the emergence of language and transition to more complex society was a process that started properly only some 40,000-50,000 years ago (for example Klein, 1995; Lewis-Williams, 2004, chp 3; for a

Figure 2: A simplified scheme of how language, practical skills, and group-size and complexity are connected

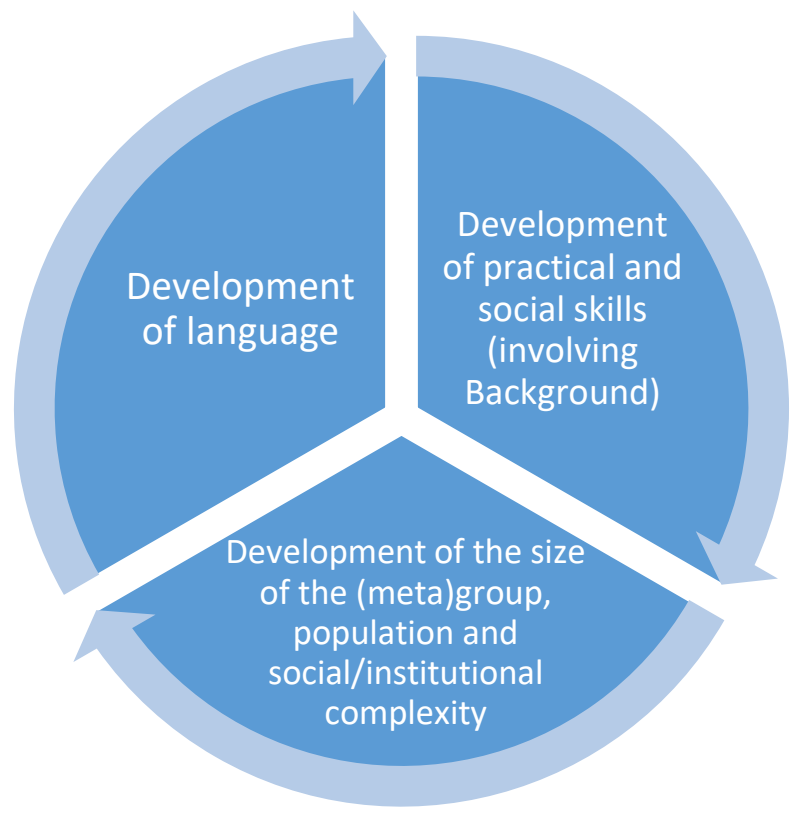

more sceptical view, Henshilwood \& Marean, 2003). What the standard view implies is that for the first 150,000 years of its existence, nothing distinguished Homo sapiens from the archaic species of 
humans. The shift from biological to cultural evolution occurred thus rather late in the history of the species (by evolution I mean a contingent process of accumulation of changes in a given system especially from simpler to more complex forms, which may or may not be progressive in some sense). This indicates that emergence beyond nature must have been an awkward process.

The scheme of Figure 2 depicts a continuous process and this has major implications for social ontology. It is not only that there is more than one essential stage of emergence leading from biology to society; there are also changes and emergence occurring in an accelerating manner within stages of this long and complex process (for a relatively detailed account of the first seven stages, see Appendix ${ }^{3}$ ). The evidence of the emergence of language and culture is often indirect and speculative. For instance, anatomically modern humans went to Australia some 50,000 years ago, perhaps even earlier. DNA studies and demographic modelling indicate hundreds of individuals coming to Australia together, suggesting deliberately organised sea travel. From this it is inferred that humans must have gone there by some sort of boats, perhaps rowing across waters unable to see land. The building of something as complicated as boats and navigating them across sea requires language and a sufficient degree of social complexity. However, the idea that humans must have gone to Australia by boats is an abstract, model-based speculation. There is no direct evidence and the exact circumstances of humans arriving in Australia are not known (Westaway, 2019).

What is more persuasive is that at around this time various new artefacts started to appear in Eurasia indicating new qualities and powers of humans and increasing size and complexity of human communities. Cultural knowledge can only be passed on if there are enough tool- or art-makers in contact with enough other talkers. The concept of cumulative culture implies a shift from biological to cultural evolution. The expansion of the size of the (meta)group was a slow process and it is likely to have occurred hand in hand with the evolvement of primitive and then, over time, more complex forms of language. The development of language was gradual. It was especially slow compared to later historical scales of time, but started to accelerate. With complex oral language, humans can continue activities over time and concentrate on a task (for how a typical individual boat-builder in a Polynesian chiefdom repeatedly yells commands to himself as "us", see Wright, 2009 , p. 50). Capacity to concentrate is clearly a benefit for survival and likely cause of population growth among those groups that adopted complex language. Development of intentionality and population growth can then be linked back to the size of the (meta) group (Figure 2).

Emergence means that elements are combined and organised in a novel way, resulting in new qualities and causal powers. The process of emergence takes time. In the process, the pre-existing elements may assume new functions. Hence the causes of their development can be different from the causes of their reproduction and development in a new context. Although it is true that evolution and history sometimes exhibit discontinuities or "jumps", it seems more plausible to suggest that the linguistic form emerged from interactions between multiple processes and through different mechanisms at several different time frames from phylogenetic and epigenetic to developmental, historical (longue durée and shorter durations), and interactional. Changes in linguistic abilities must arise in parallel with advances in cognitive or social abilities. (Cangelosi, 2005, p. 187; MacWhinney, 2005, p. 194). To reiterate, the process was at first very slow and accelerated through time as cultural and social processes and mechanisms became more central.

What is important from an epistemic and scholarly viewpoint is that the resulting new qualities and causal powers are observable in the archaeological record. Each shift has enabled bringing in new resources, inventing new tools, adding elements and their relations to language, adjusting rituals and practices, and so forth. An important indication of these changes is the emergence of cave paintings, signalling the capacity to imagine or literally dream absent things (typically animals or other 
humans). With learning transmitted through metagroups and culturally from generation to generation, a point arrived when the human metagroups started to acculturate plants and animals (at this stage, they could not fully differentiate the human from the natural, and they were living in an animistic world). Domesticated plants and animals evolved and changed also biologically (higher levels of reality can be causally efficacious with regard to lower level). The next fundamental level emerged when human metagroups combined with domesticated plants and animals to form new cultural systems of life-support. Agrovillages that soon evolved into small towns formed a new energy-system: 'the sunlight was converted into food energy by the green fields of crops now 'inside' the cultural system' (Volk, 2017, p. 135; on the economics of early farming, Diamond, 1999, pp. 104-13). This account accords with the primacy of practial action in the sense of Archer and Lawson, but producing food and tools is only a part of the story (see below).

The scheme of Figure 2 can easily be made more dialectical, contingent and open-ended. For instance, Joseph A. Camilleri and Jim Falk (2009) propose a trans-historically applicable scheme of development of the type: more complexity $\rightarrow$ more efficiency $\rightarrow$ larger population but new problems $\rightarrow$ learning and changes in consciousnss $\rightarrow$ more complexity. These connections are contingent. Learning is not automatic and can also be regressive. Problems can also be social and intersocietal, not only practical in the sense of foreaging, hunting, work, or production. Metagroups and larger societies can regress - and populations can collapse - for a variety of reasons and due to manifold causal processes. Learning can take developments into different directions, albeit within the limits of possibilities set by the underlying biological realities and prevailing forms of mind (corresponding to culturally co-determined development of brain structures) and social structures.

\section{On the ontological consequences of the hypothesis of "bicameral" mind}

From an ontological point of view, the most important part of the story concerns the development of language and consciousness, enabling and constraining the development of social complexity, and vice versa. What the social ontologies of Searle and critical realists describe is a literate and secularised world of humans with reflective consciousness and capacity for reflexively monitoring and evaluating their own actions as well as social relations, rules and principles (even when most of their everyday practices are based on unconscious rule-following). The worlds of cave-painting communities, chiefdoms and early civilizations were in all likelihood very different.

Searle and his followers may or may not agree with the idea that the properties and powers of the mind evolve in social contexts, but critical realists have widely accepted that language and social interactions are essential to the process in which mind and consciousness emerge in human individuals as they grow and mature (for example Baggio, 2020). This emergence requires a social context, in which others are not only intentional and cooperative but also reflectively conscious. The difficulty lies in imagining a context where language is either very elementary or at least nonmetaphorical, where there is no metaphorical space for introspection, and where time cannot be imagined in a spatial way. What kind of mind and consciousness could emerge in such a social context? With no introspective space for reflections or reflexivity in others, people evolving in interaction with those others and prevailing forms of language could not have developed the inner conversation that is essential for Archer's realist social ontology (Archer, 2002, 2010, p. 4, citing Plato's Theaetetus as the first characterisation of reflexivity). They would have lacked also Searle's (for example 1995, p. 32) self-referential concepts. In a like manner, people in these early settings would not have been able to monitor the monitoring of their performances or provide commentary upon them, both essential for Bhaskar's transformational model of social activity (Bhaskar, 1998, p. $38)$. 
Such contexts must have existed until some (pre) historical point. It follows that the emergence of the first reflectively conscious humans must have been an outcome of a long geo-historical process. A highly original and plausible analysis of such a process remains Julian Jaynes's The Origin of Consciousness in the Breakdown of the Bicameral Mind (2000). Written in the 1970s, this book remains controversial because of its radical implications, even though it is consistent with the standard view, according to which the first "modern" humans in Africa did not have complex verbal language. Jaynes's theory also accords well with the current view that language emerged from interactions between multiple processes and through different mechanisms at several different time frames from phylogenetic and epigenetic to developmental, historical, and interactional. It is also in line with synchronic emergent powers materialism and with the idea that higher-order principles of the mind cannot be completely explained in terms of lower-order ones and that the former may have a logic of development of their own, within the constraints and possibilities of the brain and body. Most importantly, it appears consistent also with archaeological and other forms of evidence. ${ }^{4}$

How did language evolve? Each new stage of linguistic learning created new perceptions and attentions, resulting in important cultural changes, which are reflected in the available archaeological record (see Appendix ${ }^{5}$ ). The first phase is the establishment of clearly recognisable intentional calls. Differentations in terms of intensity of calls resulted in vocal qualifiers and modifiers. With intentional calls and several qualifiers, simple instructions and commands became possible. Moreover, the evolvement of modifiers and qualifiers enabled the production of better tools. Instruction and commands also facilitated cooperation and group work in hunting, perhaps especially so in the new and often less hospitable environments where to people gradually migrated.

According to Jaynes (2000, p. 134), the next step was the emergence of referents of the modifiers or commands, that is nouns. Therefore, for the first time in human history, something like full sentences appeared. Quite logically, the first cave paintings, mostly of animals, paralleled the appearance of nouns for animals. People can imagine absent things if they have a concept for it; they can also try to make sense of their dreams and hallucinations and remember them. With these skills, perhaps as part of rituals, they can turn their visions into drawings and ornaments. (For direct evidence of collective hallucinations, Everett, 2008, pp. xv-xvii, 137; for a dream- and hallucination based theory of cave-paintings, Lewis-Williams, 2002; for defence of Jaynes's ideas, Kujsten, 2006; Williams, 2011). The thing-nouns begot new things such as pottery, pendants, ornaments, barbed harpoons, and spearheads. The new functions of language and gradual acceleration of cultural learning transformed also the human brain. The brain is a highly connected and interconnected organ, in which connections and their activations are constantly shifting. Thus evolved the language hemispheres in human brain. However, the hypothesis about strict bicamerality of the brain is not necessary for Jaynes's theory. What is more essential is the way gradually evolving language comprehension had important side effects, in terms of what he conceptualises as hallucinations of the "bicameral mind" (for example Jaynes, 2000, p. 132).

Jaynes's most controversial idea is that as language proper started to evolve, it was at first and, indeed for tens of thousands of years, experienced as something "external". An analogue to a wellrecorded historical process might help to understand this idea. ${ }^{6}$ To the modern literate person silent reading happens naturally; however, for a long time reading was only done orally. Oral reading and the nature of texts were connected. Ancient writing had no punctuation, upper or lower case or word separation. The standardisation of text and shift to silent reading went hand in hand. The first report of someone reading silently is in St. Augustine's Confessions (written between 397 and $400 \mathrm{CE}$ ). Centuries later the practice started to become more commonplance. In the fourteenth and fifteenth centuries writers began to think of themselves as writers, addressing their texts to the reader rather 
than to the listener - and yet, still in the $19^{\text {th }}$ century reading remained a social event for many people.

Jaynes's basic hypothesis about the "external" nature of language is analogous with this process; it may also be taken to describe an earlier phase of the same process. When language evolved, it was for a long time spoken without any reflectively conscious "I" controlling it. To avoid misunderstandings, it is important to stress that reflective or introspective consciousness is not necessary for many higher mental processes, even though it can make a critical difference in terms of possible social formations. Overall, it took tens of thousands of years before the stabilisation and complexity of language reached the stage of constituting an internal "space-to-move". What is more, the externality of language was systematically intertwined with dreams, mental images and hallucinatory experiences, some of them self-induced. The human mind evolved together with language and social complexity, but it lacked in conscious introspection, executive control, and the ability to explicitly reason about and articulate intentional actions. What is especially striking but also interesting about Jaynes's theory is the claim that reflective consciousness materialised no earlier than in the first millennium BCE, during what Karl Jaspers (1957) calls the axial age.

Jaynes's account can explain, among other things, the steep hierarchical structure of the chiefdoms and early civilizations as well as many practices that would seem difficult to grasp otherwise. ${ }^{7}$ In chiefdoms and early civilizations, social norms were upheld by fear of gods and through various simple signs that were taken as commands. These gods were voices generated by the human brain transformed by the acquisition of language. The early human civilizations invented or adopted writing, money and mathematics, and engaged in gift-exchange, trade and wars with other communities, thus step by step paving the way for the bursting of reflective consciousness sometime later. During this process evolved also the capacity to articulate individual plans of action to the level that made standardised forms of reflective moral and legal responsibility possible. With the Code of Hammurabi (c. 1760 B.C.E.) and similar codes of law in the Near East, the principle of justice was first articulated in writing. Justice was born (as what appears to us) as a rudimentary moral accounting of equivalents. At its simplest, this meant an eye for an eye, a tooth for a tooth, but the equivalance was also understood in terms of a universal of value (shekel that was nominally equivalent to a specific weight of barley). This was a major step toward the emergence of reflectiive consciousness and reflexivity. A text such as the Code of Hammurabi outlines norms and gives commands, but is in itself silent and can, in principle, be read by anyone (Jaynes, 2000, p. 302)

Reflective consciousness and its consequences occur through language and especially by way of metaphors, which enable abstract thinking, linear narratisation, and self-reflection. In this account, at the dawn of the reflective consciousness, probably at the beginning of the first millennium BCE, bodily things such as breath, blood, lungs, heart, and head were turned into metaphors and started to denote psyche, spirit, soul, life, emotions, intelligence, and self. The repertoire of simple affects that we share with other mammals was transformed into complex human emotions: fear became anxiety, shame was translated into guilt, and mating was turned into sex. Analogues and metaphors were thus decisive for the emergence of emotions. Subsequently - a few centuries later - they enabled debates and theories about justice, goodness, morality, emotions, and the meaning of human existence.

The precise timing of this transformation is open to debate, as there is evidence for instance for Egyptian poems possibly involving the use of metaphors and literature in narrative form in the second millennium BCE (for example the well-known story about Sinuhe). The main point is that metaphor generates consciousness by creating a space in which the "I" can move and "do" things that we are not actually doing; constructs the "me" that we can imagine and see doing things that we 
may or may not be actually doing; and tell stories where the "I" and "me" moves in spatialized time (Jaynes, 2000, pp. 65-66; also Lakoff \& Johnson, 1999, pp. 139-61, 235-89). To use Searlean terminology, this historical development indicates that various (including reified, "hallucinated", and hierarchically organised) forms of we-intentionality existed long before the emergence of the reflectively conscious I-intentionality. The spatialized time, in which events and experiences can be located, remembered and anticipated, enables subjectivity, morality, law, and politics (the standard Western assumption is that politics emerged in ancient Hellas, although this is probably too Eurocentric). Actors know that they can act otherwise and thus become reflective (and possibly reflexive) about some of their doings. They can also learn that others are equally reflective conscious beings, even that they share a world of meanings. Once they have learnt this, however, it becomes difficult to imagine thousands of generations of genetically indistinguishable human beings without consciousness in the reflective sense of the term.

\section{An illustration: contrasting the Bronze Age mind with our contemporary world}

What is conventionally called "world history" starts typically with the history of the Mesopotamian, Indian and Chinese hubs of the old world (see for example McNeill \& McNeill, 2003). It includes, among other things, stages of political economy developments that led, thousands of years later, to the rise of liberal capitalist market society and the Industrial Revolution. There is no space to discuss all the numerous micro-emergencies and complexifications of mind and society that have occurred during the past 2,000-3,000 years - not even those have that have occurred during the past 200-300 years - many of which can be considered rather fundamental. Suffice it to recall Searle's brief history of money as an illustration of how also the capitalist market society has been changing. ${ }^{8}$ To conclude my argument, I offer a simple illustration of the mental distance between the Intermediate Bronze Age world of Mesopotamia and our contemporary global world by comparing the Code of Hammurabi with contemporary theories of democratic justice. To set the scene, a few quotations from the laws of Hammurabi:

- 'If anyone bring an accusation against a man, and the accused go to the river and leap into the river, if he sink in the river his accuser shall take possession of his house. But if the river prove that the accused is not guilty, and he escape unhurt, then he who had brought the accusation shall be put to death, while he who leaped into the river shall take possession of the house that had belonged to his accuser.'

- 'If anyone take a male or female slave of the court, or a male or female slave of a freed man, outside the city gates, he shall be put to death.'

- 'If the wife of a man has been caught lying with another man, they shall bind them and throw them into the waters. If the owner of the wife would save his wife then in turn the king could save his servant.'

For Lawrence Kohlberg (1981), the highest stage (to date) of our moral learning corresponds to John Rawls's (1971) principles of democratic justice. Kohlberg's claim about "stages" may be controversial, but when pressed, few sceptics of historical progress would deny that the Rawlsian notion of justice or any other well-known $20^{\text {th }}$ century conception is not only more sophisticated and complex but also more adequate than the one codified in the Code of Hammurabi (for explicit justification, see Kohlberg, 1971, 1973). The Rawlsian principles are not declared to the subjects by a god-fearing and probably still hallucinating king. The river does not decide who is to be punished by death, there are no slaves, wives are not owned, and nobody can decide arbitrarily whether someone else should be saved from drowning or be killed. 
Rather, there is a clear effort to justify generalisable ethico-political principles and persuade one's audience in both scholarly and democratic dialogue. The principles are expected to have validity and application apart from the authority of the groups or persons holding these principles, and apart from any of the individuals own identification with these groups. Right is defined by the decision of conscience in accord with the self-chosen ethical principles appealing to logical comprehensiveness, universality, and consistency. For example, when explaining the grounds for the right to civil disobedience in a democratic society, Rawls (1971, p. 367) writes that "to be completely open and nonviolent is to give bond of one's sincerity, for it is not easy to convince another that one's acts are conscientious, or even to be sure of this before oneself". In this scheme, actors are committed to nonviolence; what is more, the subject "I" can even doubt the sincerity of the object "Me".

Ethical and political developments have not stopped with Rawls. Jürgen Habermas (1990) is more explicit than Rawls (also compared to Rawls, 1985) about the need for a real dialogue concerning rules, norms, and principles. Jacques Derrida in turn points to the difficulties of creating ethicopolitical spaces free from asymmetries and biased relations of power. As a partial solution to the problem of making normative judgements, Derrida (1988, p. 128) proposes the "extreme complication, multiplication, explication of precise and rigorous distinctions"; and the notion of undecidability as "a determinate oscillation between possibilities (for example, of meaning, but also of acts)" (1988, p. 48). His approach is to deconstruct binary structures within language and, simultaneously, cultivate critical awareness of the metaphorical and other conditions of reflective consciousness. The aim is to create the conditions for a democracy to come, in which justice means extended and deepened non-violence as well as mutual respect for the other, and in which all subjects reflexively understand that their subjectivities are effected in and through language (writing). Bhaskar qualifies Habermas's reasoning in some original ways, while being also critical of Derrida's deconstructionism. Bhaskar (2008b, p. 137) sees Habermas and Derrida as complementary and formulates his critique in sharp terms:

Properly conceived the programmes of deconstructive semiotics [of Derrida] and reconstructive hermeneutics [of Habermas] are not only consistent but interdependent, betokening the interdependence of the mediate and immediate, the duality of structure and agency, [...]. What they share in common is an irrealist, unstratified, actualist, and arguably a punctualist and/or blockist and/or closed ontology - and in particular an insufficiently stratified and distanciated concept of the self and space-time.

This brings me back to the main thesis of this paper. To avoid irrealist, unstratified, actualist, blockist and/or closed ontology, and an insufficiently stratified and distanciated concept of the self, social ontology should be temporalized and historicized. Moreover, contemporary nation-states and liberal capitalist societies (or their particular late $20^{\text {th }} /$ early $21^{\text {st }}$ century Anglo-American manifestations) do not represent the end of history. World history is an on-going process, in which discussions about, say, theories of democratic justice, new forms of reflexivity, and conditions of ecological and social sustainability play an important role. In line with the dialectical, contingent and open-ended interpretation of Figure 2, we should not only expect a variety of micro-emergence. We may also expect new levels with new kinds of relations and organized wholes building from entities, structures and processes of the prior level. "At the planetary scale, an expanding phenomenon - geochemical, biological, cultural - closes back upon itself [...; ] all peoples and lands are already on the inside" (Volk, 2017, p. 197). Mind evolves and in the new emerging social imaginary, the conditions of good life are taken to be planetary and increasingly dependent on what we interconnected humans do. For instance, climate change implies that there is no automatic planetary homeostasis, at least not in the human scales of time. For a globalist mind of this kind, homeostasis must be generated by purposeful means, requiring new cooperation on a global scale. 


\section{Conclusions}

In our almost completely literate and partly secularised contemporary world of the $21^{\text {st }}$ century, where humans possess reflective consciousness and the capacity to evaluate actions, rules and principles, we can see that words and concepts are historical. Words and concepts not only emerge but can also evolve, branch, change, and disappear. As language is in part constitutive of social realities (or institutional facts), this kind of conceptual complexification implies a diversity of possibilities in any given era of geohistorical development. This is so even given the limits of possibilities set by the underlying physical and biological realities; prevailing forms of mind and social structures; and pressing practical problems, which are now increasingly shared and global. Moreover, each era includes elements or remnants from earlier eras. Developments can converge but they may also diverge and be combined in a variety of ways. Regress and collapse remain latent possibilities in every era. The oftentimes contradictory processes whereby developments in language, practical competencies, and complexity feed into each other will not come to an end unless there is an end to the life or human civilization as such. With new technological capabilities and global interconnectedness, however, an end to human civilization is now a genuine possibility.

A realist social ontology must avoid the idea of fixed forms of being, relations and wholes. It is important to frame this conclusion in a nuanced way. Whether a general ontological/theoretical category or concept is adequate may concern primarily various competing theories and their claims about a given socio-historical world (level of knowledge); but their adequacy may also be about the way the historically changing world itself evolves (level of being). My main point has been to stress the latter. The processual and changing nature of being should be an explicit feature of social ontology. In a parallel manner, we must consider the right level of abstraction. Philosophical ontology is more abstract and general than scientific ontology. Philosophical ontology describes the world presupposed by scientific practices as such, at the most general level (for example the world must be differentiated, structured, layered, open-systemic, and causally efficacious) whereas scientific ontology specifies the particular types of entities and processes postulated by some substantive scientific theory (Bhaskar, 2009, pp. 24-5). My point is that social ontology is somewhere between the two levels, but closer to scientific ontology. Social ontology is not a (philosophical) field in its own right, but dependent on substantive practices of social sciences and humanities. Its value lies in facilitating better scientific understandings and explanations of reality. Finally yet importantly, because complex modern society is concept- and activity-dependent, even abstract concepts such as those of philosophical or social ontology can shape society. Various concepts and theories have been and are reflexively involved in the regulation and constitution of practices and systems.

Although there are no fixed forms of being, relations and wholes, some generic claims are obviously possible, for example: language is co-constitutive of social realities. And yet the role and makeup of language has changed over the course of history and it is likely to continue doing so, in part because of technological developments such as social media and artificial intelligence as they evolve in particular social contexts. Some ontologically oriented concepts such as background, social causation, deontology, habitus, power, positioning, or status function can plausibly be seen as widely applicable. Some generic ontic categories such as reasons as causes; agency as constituted by regulative and constitutive rules; resources as competencies and facilities; institutions as practices sedimented in the longue durée of social life; social systems as organised also in terms of collective actors and the systems they form and so forth; may well be adequate in describing the contemporary world based on reflective consciousness, explicit I-intentionality, legality and high reflexivity (for an outline along these lines, see Patomäki, 1991, 2002, chap. 4). Such concepts and categories are nonetheless best conceptualised as existential hypotheses about changing processual 
realities. Thus they are about "processes-in-product", while these products are themselves in process (see Bhaskar, 2008b, pp. 5, 36, 98, 185-6). Processes-in-product reflect the specific geohistoric realities from which they have emerged, and in our current world these processes embrace not only diversity but also ambivalences and contradictions (compare note 7).

Social ontology raises fundamental questions about emergence, causation, mind, agency, structure, and such like, but it is neither "metaphysical" nor about unchanging fundamental substances. Social being is historical and history involves contingency and is open-ended. Social ontology must also recognise its own historicity. A parallel ethical and practical point is that social ontology should avoid Whig-histories and what Pierre Bourdieu and Loïc Wacquant call "the cunning of imperial reason". More generally, social ontologists should be critically reflexive partakers of history. Social ontology is best conceived as a theoretical aspect of historical social sciences and futures studies, sensitive to contexts and geo-historically evolving differences (within and across languages; see note 1). For instance, the futurized nature of the present is arguably changing through reflexive selfregulation of social systems; with increasingly reflexive, holistic and future-oriented self-regulation of systems, the very temporality of human existence is being transformed (Patomäki, 2011).

In this paper, I have also alluded to the possibility of studying historical developments in terms of stages of classical political economy, moral learning, or something else, or some combination of these. Stages mean that there is a series of abstract positions or stations in a logical order, historical order of emergence, and/or causal order understood in terms of enablement. Stages may co-exist, overlap, and form various constellations, just as relational practices and structures can form manifold heterogeneous groupings and constellations. For instance, in terms of production and use of energy, these three political economy stages may be distinguished: (1) The stage of huntergatherers, who can handle fire and simple tools but have no other sources of energy than they can gather with their own muscles; (2) the stage of agricultural civilisation, where sunlight is converted into food energy by the green fields of crops and animals now evolving "inside" the cultural system, and where the main source of energy for practical work is human and animal muscle, while increasingly also wind, water flows and chemical explosives are being exploited; and (3) the stage of industrial civilisation, based on the work of machines operated with external sources of energy, such as fossil fuels, wind or water flows, and nuclear power, transformed into electricity. Because of anticipated climate change, a new stage focussing on long-term renewability is rapidly emerging.

Any claim about "stages" is an abstract summary of some aspects of past developments and their essential features organised in logical, conceptual and/or causal terms. As abstract hypotheses, they are fallible and likely to provide only partial insights. For instance, the lower stages of cognitivemoral learning of Kohlberg (1981) and Habermas (1979) do not fully correspond to the development of collective human history. Habermas goes beyond Kohlberg in combining political economy accounts and theories of moral learning, but fails to appreciate the 'strangeness' of the minds of the early civilizations. These people were not like children in liberal-democratic capitalist society. They advanced we-intentionality and were capable of complex and long-lasting collective operations. Some of the projects of early civilizations lasted for decades or more. Yet these people lacked reflective consciousness. The prevailing theories about stages of learning seem better at capturing some aspects of recent history and at illuminating (especially secular) phenomena that are part of our "modern" world, but as such they are incomplete - as the contributions of thinkers such as Derrida and Bhaskar indicate. Moreover, thus conceived, the idea of "stages" is compatible with various genealogical methods that call into question social categories that are commonly taken to be "natural", obvious, or in some sense transhistorically necessary. 
My main point, however, is that social ontology should focus on historical processes and evolving structural possibilities. None of the existing theories is more than a transient attempt at understanding changing social realities. Antecedently established knowledge can be used to generate new knowledge. This process can be conceptualised in terms of Aristotelian material causes. The historicity of concepts is part of the transitive dimension of science and philosophy, understood as the material causes of knowledge production consisting of existing theories, technologies, practices and so forth. (Bhaskar, 2008, p. 6) Concept-formation and knowledgeproduction are reflexively involved in real historical developments, which include the possibility of essentially new layers of emergence. In this sense, social scientists may, at times, be midwifes of world history.

\section{Appendix: stages of development from the era of archaic humans to the axial age}

The oldest known skeleton of an anatomically modern Homo sapiens dates to about 200,000 years ago. It is widely agreed in archaeological and anthropological literature that the emergence of language and transition to "modern" behaviour occurred some 40,000-50,000 years ago. It seems that a few preliminary changes preceded this transition some 70,000-50,000 years ago, at the time when humans started to move out of Africa (e.g. Klein, 1995; Lewis-Williams, 2004, chp 3; for a more sceptical view partly based on methodological problems, see Henshilwood \& Marean, 2003). What the widely agreed view implies that for the first 150,000 years of its existence, nothing distinguished Homo sapiens from the more archaic species of humans, with which it much later interbred in various parts of Eurasia.

Many sources suggest that during the transition some 40,000-50,000 years ago, a "fully modern" behaviour, consciousness, mind, and/or language would have emerged quite abruptly. What "abrupt" means in this context is rarely discussed. In social sciences, a longue durée of history - the longest conceivable period of continuity at some level of social reality - is supposed to take from a few hundred up to a thousand years (see Braudel, 1980). How "abrupt" can a process of change be that lasts a few thousands of years if not more? In itself, this question is suggestive of the acceleration of processes of change over time, requiring explanation. In any case, Table 1 summarises the idea that there was a sudden change after a long period of continuity that lasted, in essence, for about two million years counting from the beginning of the era of homo erectus. This view is usually associated with the idea that some kind of genetic or neural change must have caused the transition, though it would be difficult to explain how a genetic change could have occurred so rapidly across the world. The more plausible explanation focusses on the capacity of the brain to restructure itself on the basis of experiences and communications and in terms of its networks of neurons and synapses. The neuronal-synoptic change may result from this autopoetic (self-producing and self-creative) capacity, which, after a certain turning point, is capable of enabling lasting forms of emergence also in the absence of any significant (epi) genetic change.

In the simple model of Table 1, the transition is assumed to have occurred between two types of consciousness, "primary" and "higher-order". Primary consciousness is present-centric and involves no language. The idea is that after the transition, humans suddenly have the capacity for "full" or "fully modern" temporality, understanding of "we", conception of self, and modern language (whatever that may mean), as they are by now living in large and complex societies where social distinctions and also conflicts occur. Since then, humans would have remained the same, implying 
Table 1: A simple dichotomist view of two forms of consciousness

\begin{tabular}{|c|c|c|c|c|c|c|}
\hline $\begin{array}{l}\text { Primary } \\
\text { conscious- } \\
\text { ness }\end{array}$ & Present-centric & $\begin{array}{l}\text { No concept } \\
\text { of a } \\
\text { personal } \\
\text { self }\end{array}$ & $\begin{array}{l}\text { No capacity to view } \\
\text { images from the } \\
\text { vantage point of } \\
\text { social self }\end{array}$ & $\begin{array}{l}\text { No } \\
\text { language }\end{array}$ & $\begin{array}{l}\text { No social } \\
\text { distinctions }\end{array}$ & Size and complexity: primary bands of c. 30 individuals \\
\hline $\begin{array}{l}\text { Higher } \\
\text { order } \\
\text { conscious- } \\
\text { ness }\end{array}$ & $\begin{array}{l}\text { Capacity to see } \\
\text { the past and the } \\
\text { future }\end{array}$ & $\begin{array}{l}\text { A } \\
\text { conception } \\
\text { of self }\end{array}$ & $\begin{array}{l}\text { Recognition of his } \\
\text { or her acts or } \\
\text { affections from the } \\
\text { point of view of the } \\
\text { collective self }\end{array}$ & $\begin{array}{l}\text { Fully } \\
\text { modern } \\
\text { language }\end{array}$ & $\begin{array}{l}\text { Social } \\
\text { distinctions, } \\
\text { diversity, } \\
\text { discrimination, } \\
\text { conflicts }\end{array}$ & $\begin{array}{l}\text { Size and complexity: organized settlement patterns and } \\
\text { extensive "trade" in specialised items } \rightarrow \text { a loosely } \\
\text { organised network of primary bands, with the core bands } \\
\text { spending a part of the year together }\end{array}$ \\
\hline
\end{tabular}

Sources: Summarised from Edelman 1992, 113-32; Lewis-Williams 2004, 69-100 
that there is no essential difference between a shaman from 30,000 BCE and John Searle or Tony Lawson. (See Table 1 above)

From a scientific or critical realist perspective, emergence means that elements are combined and organised in a novel way, resulting in new qualities and causal powers. The process of emergence takes time. In the process, the pre-existing elements may assume new functions. Hence the causes of their development can be different from the causes of their reproduction and development in a new context. Although it is true that evolution and history sometimes exhibit discontinuities or "jumps", it seems more plausible to suggest that the linguistic form emerged from interactions between multiple processes and through different mechanisms at several different time frames from phylogenetic and epigenetic to developmental, historical (longue durée and shorter durations), and interactional. Changes in linguistic abilities must arise in parallel with advances in cognitive or social abilities. (Cangelosi, 2005, 187; MacWhinney, 2005, 194). The gradual emergence of culture and society from nature may have involved periods of rapid change, but in general the process was at first very slow and accelerated through time as cultural and social processes and mechanisms became more central (like all layers of reality, culture remains dependent on earlier and lower layers). What is important from an epistemic viewpoint is that the resulting new qualities and causal powers are observable in the archaeological record.

The starting point of Table 2 is that the emergence of language, consciousness and complex society has been a long process with multiple phases. Its end-point, however conceived and located, is not "fully modern", but rather something that remains subject to further open-ended developments. From this perspective, the apparent discontinuity of Table 1 would seem to require an almost miraculous neural (or genetic) change in the anatomically modern homo sapiens, in spite of the complexity of numerous anatomical, cognitive, social and ecological elements that played a role in the slow and multi-phased emergence of language and reflective consciousness. Here I can only give a literature-based and indicative account of some of the developments that were involved in this long and complicated process (the summary of Table 2 accords also with the basic thrust of Tomasello's [2008] well-known constructivist theory of language development). A vast variety of distinct complexity-increasing mechanisms and systems (cf. Clayton, 2013) contributed to the gradual adaptation of human systems in ecological contexts. It is worth stressing that only hominins started to adapt by means of developing social intelligence and cooperative skills and by increasing group size. This was only an evolutionary option among many, as for instance the line leading to the current chimpanzee illustrates.

The point of Table 2 is to illuminate the steps required before a Searlean or CR social ontology may be even remotely adequate. The table depicts seven stages of development. It is based on the idea that cognitive and communicative capabilities, size of relevant groups and metagroups, population density and ecological conditions are intra- and interrelated in multiple ways, including in terms of opposing causal tendencies. A given narrow ecological niche in an area can sustain only a very small number of people. A shift to larger size is thus difficult. To increase the size, new qualities and powers must evolve, but they in turn would already presuppose larger communities. A problem is that in primates, social complexity increases rapidly with group size, and social complexity requires enhanced cognitive powers and larger brains (Donald, 1991, 137). The transition from stage 1 to stage 2 was occurring through (epi) genetic changes and was very slow. Also the transition from stage 2 to stage 3 took at least 1.5 million years. It was only after the emergence of culture that the process started to accelerate. 
Table 2: Seven stages from primary consciousness to the ancient world

\begin{tabular}{|c|c|c|c|c|c|c|c|}
\hline $\begin{array}{l}\text { 1. Primary } \\
\text { consciousness }\end{array}$ & $\begin{array}{l}\text { Communication } \\
\text { through variety of } \\
\text { signals mostly } \\
\text { genetically } \\
\text { determined (some } \\
\text { intentionality) }\end{array}$ & $\begin{array}{l}\text { No capacity to view } \\
\text { images from the } \\
\text { vantage point of } \\
\text { social self }\end{array}$ & $\begin{array}{l}\text { No concept of } \\
\text { personal self, but } \\
\text { ability } \\
\text { of self-identification } \\
\text { in front of a mirror }\end{array}$ & Present-centric & $\begin{array}{l}\text { Tools are invented } \\
\text { and used ad hoc, not } \\
\text { transmitted } \\
\text { culturally }\end{array}$ & $\begin{array}{l}\text { Social structure } \\
\text { established at } \\
\text { present \& is } \\
\text { dominated by strong } \\
\text { males and their } \\
\text { sexual drive }\end{array}$ & $\begin{array}{l}\text { Size and complexity: } \\
\text { primary bands of c. } 15- \\
30 \text { individuals }\end{array}$ \\
\hline $\begin{array}{l}\text { 2. Culture based on } \\
\text { imitation }\end{array}$ & $\begin{array}{l}\text { Communication } \\
\text { through variety of } \\
\text { complex signals } \\
\text { that are } \\
\text { increasingly } \\
\text { intentional }\end{array}$ & $\begin{array}{l}\text { Sociability, inherent } \\
\text { capacity to } \\
\text { understand others' } \\
\text { intentions and } \\
\text { imitate }\end{array}$ & $\begin{array}{l}\text { No concept of } \\
\text { personal self, but as } \\
\text { above \& self- } \\
\text { initiated and } \\
\text { representational acts } \\
\text { that are intentional, } \\
\text { though not } \\
\text { linguistic }\end{array}$ & $\begin{array}{l}\text { Implied future- } \\
\text { orientation } \\
\text { (danger, design of } \\
\text { artefacts etc) }\end{array}$ & $\begin{array}{l}\text { Stone-made tools, } \\
\text { but little if any } \\
\text { developments in the } \\
\text { scale of } 10^{5} \text { years }\end{array}$ & $\begin{array}{l}\text { Egalitarian sharing; } \\
\text { social } \\
\text { differentiation } \\
\text { unclear; probably } \\
\text { some sexual } \\
\text { division of labour }\end{array}$ & $\begin{array}{l}\text { Size and complexity: } \\
\text { primary bands of c. } 15- \\
30 \text { individuals, size } \\
\text { perhaps slowly } \\
\text { increasing, with (quasi-) } \\
\text { regular interactions with } \\
\text { other similar bands }\end{array}$ \\
\hline $\begin{array}{l}\text { 3. First elements of } \\
\text { spoken language: } \\
\text { intentional calls, } \\
\text { modifiers and } \\
\text { commands }\end{array}$ & $\begin{array}{l}\text { Commands } \\
\text { emerging from } \\
\text { intentional calls } \\
\text { and modifiers } \\
\text { (e.g. "sharper"!) }\end{array}$ & $\begin{array}{l}\text { Responsiveness to } \\
\text { others and their } \\
\text { intentions (tacit } \\
\text { recognition of the } \\
\text { social self) }\end{array}$ & $\begin{array}{l}\text { No concept of } \\
\text { personal self, but as } \\
\text { above \& intentional } \\
\text { acts partly linguistic }\end{array}$ & $\begin{array}{l}\text { Implied future- } \\
\text { orientation } \\
\text { (danger, design } \\
\text { etc), with wider } \\
\text { action- } \\
\text { possibilities }\end{array}$ & $\begin{array}{l}\text { New types of tools } \\
\text { that require more } \\
\text { concentration and } \\
\text { learning; increasing } \\
\text { diversity of } \\
\text { materials }\end{array}$ & $\begin{array}{l}\text { Minor social } \\
\text { differentiation, } \\
\text { involving also tacit } \\
\text { claims to } \\
\text { knowledge } \\
\text { (shamans, teachers) }\end{array}$ & $\begin{array}{l}\text { Size and complexity: } \\
\text { the density of } \\
\text { population increases } \\
\text { and the wider networks } \\
\text { start to become more } \\
\text { organised }\end{array}$ \\
\hline $\begin{array}{l}\text { 4. Nouns \& some } \\
\text { rules of language- } \\
\text { use }\end{array}$ & $\begin{array}{l}\text { Once modifiers } \\
\text { and commands } \\
\text { stabilised, nouns } \\
\text { for life/animals } \\
\text { and first } \\
\text { rudimentary } \\
\text { sentences evolve; } \\
\text { gradually also } \\
\text { nouns for things }\end{array}$ & $\begin{array}{l}\text { The social self } \\
\text { occurs though } \\
\text { hallucinated images } \\
\text { and commands that } \\
\text { drive activities from } \\
\text { tool-making to } \\
\text { cave-paintings }\end{array}$ & $\begin{array}{l}\text { No concept of } \\
\text { personal self, but as } \\
\text { above \& ritual } \\
\text { burials suggest that } \\
\text { some individuals } \\
\text { are already } \\
\text { assuming special } \\
\text { significance }\end{array}$ & $\begin{array}{l}\text { Images \& } \\
\text { enduring complex } \\
\text { tasks } \rightarrow \text { non- } \\
\text { present becomes } \\
\text { real, also through } \\
\text { dreams and } \\
\text { hallucinations } \\
\text { (other-worldly) } \rightarrow \\
\text { cave-paintings }\end{array}$ & $\begin{array}{l}\text { Further } \\
\text { diversification of } \\
\text { tools and the } \\
\text { emergence of } \\
\text { drawing of animals; } \\
\text { and then invention } \\
\text { of pottery, pendants, } \\
\text { ornaments, barbed } \\
\text { harpoons and } \\
\text { spearheads }\end{array}$ & $\begin{array}{l}\text { The emergence of } \\
\text { social distinctions, } \\
\text { diversity, } \\
\text { discrimination \& } \\
\text { conflicts in what } \\
\text { still remains partly } \\
\text { egalitarian and non- } \\
\text { differentiated } \\
\text { context }\end{array}$ & $\begin{array}{l}\text { Size and complexity: } \\
\text { tribal metagroups, } \\
\text { establishing a wider } \\
\text { "we" of togetherness } \\
\text { (acting together, } \\
\text { coordinating activities } \\
\text { also across seasons etc) } \\
\rightarrow \text { further stabilisation } \\
\text { of language }\end{array}$ \\
\hline $\begin{array}{l}\text { 5. Names \& } \\
\text { context-sensitive } \\
\text { and partly still } \\
\text { unstable syntax and }\end{array}$ & $\begin{array}{l}\text { With larger \& } \\
\text { fixed populations } \\
\& \text { social } \\
\text { differentiation, } \\
\text { individuals start to } \\
\text { be identified by }\end{array}$ & $\begin{array}{l}\text { Hallucinated images } \\
\text { and voices can be } \\
\text { named } \rightarrow \text { social self } \\
\text { assumes new forms } \\
\text { of existence, and it } \\
\text { is in this context }\end{array}$ & $\begin{array}{l}\text { The concept of } \\
\text { personal self } \\
\text { evolving, e.g. } \\
\text { ceremonial graves } \\
\text { become a common } \\
\text { practice } \rightarrow\end{array}$ & $\begin{array}{l}\text { As in stage 2, but } \\
\text { other-worldliness } \\
\text { becomes more } \\
\text { clearly } \\
\text { articulated; } \\
\text { hallucinations }\end{array}$ & $\begin{array}{l}\text { Language allows for } \\
\text { greater } \\
\text { individuation of } \\
\text { things, bringing } \\
\text { about more } \\
\text { sophisticated and }\end{array}$ & $\begin{array}{l}\text { Social } \\
\text { differentiation } \\
\text { increases and } \\
\text { becomes more } \\
\text { established } \\
\text { involving conflicts, }\end{array}$ & $\begin{array}{l}\text { Settlements become } \\
\text { more permanent and } \\
\text { metagroups larger; } \\
\text { rudimentary } \\
\text { experimentation with } \\
\text { agriculture; over time }\end{array}$ \\
\hline
\end{tabular}


other rules of

language-use

names; ful

sentences;

syntactical

language with

subject-object-

verb structure

6. "Bicameral

mind": symbolic

language, book-

keeping and

eventually writing,

mathematics and

justice; writing:

proceeding from

pictures of visual

events to symbols

of phonetic events;

syntax and other

rules consolidated

7. Reflective

consciousness and

agency: emergence

of metaphorical

mind-space, the

analogy "I", the

metaphor "me",

narratisation,

compatibilisation

etc.; written

language can fix

meanings and rules

across contexts

Syntax \& rules

become more

stable as

language-use

becomes

ritualised in a

concepts and

expressions

evolve

e

Oral stories

copied in a

ocuments and

letters become

more common-

place; the

beginning of

philosophy,

of words, that not only named

gods but also, strict

coordination

problems start to

emerge

larger community

and as new words,

written down and

canonised form;

science, and arts;

further expansion

concepts and

expressions

Hierarchy emerges

as a solution to the

coordination

god, voice of god

through king and

large temple \& an

organised religion

with specialised

roles, tied with a

system of

production and

distribution, is the

social self.

Collective self

evolves in

interaction with

personal self;

possibility of

reasoned dialogue;

hierarchies, justice,

truth and also gods

are questioned; this

questioning remains

rare and is

conditioned by

older layers and

scales of efficient

communication individuals are

recognised as

pehaviour

remembered also

after their deaths

problem: a powerful

The dead and

especially dead

kings speak long

fter death; but also

their replacements,

god-statues etc

appear to speak and

demand sacrifices;

the collective whole

(= god) assesses

individuals

identified with

names, e.g. in terms

of justice

People not only

have a personal self

but can also

systematically

cultivate it; gods

become increasingly

silent; what they or

god-like teachers

once spoke, can be

written down and

the text treated as

holy; for some gods

are only objects of

human belief
Long-term

projects (future)

and long-distance

xchange (spatial

outside) become

possible;

acrifices for the

god; afterlife

(burials with food,

tools and weapons

rovided for the

dead etc) diverse artefacts \&

accumulation of

cultural knowledge

about plants and

animals

Further

individuation of

things, bringing

about more

sophisticated and

diverse artefacts \&

accumulation of

cultural knowledge

about plants and

nimals, resulting in

domesticated

animals and

collectively

organised

agriculture

Utopian thinking

and linear time

evolve \& soon

questioned and

debated; long-

term projects and

designs still focus

largely on afterlife

and gods, apart

from military

issues; other-

wordliness is

nonetheless no

longer self-

evident art, artefacts and technology in the

hubs of the Old

World; capacity for

long-distance sea-

travel and

navigation; horses

make land-

communication and

travel faster;

ominant forms in

the hubs: city-states

and military-

agrarian empires
New (for us ancient) which are difficult to resolve without a strict hierarchy

based on the

authority of gods

Social

differentiation and

steep hierarchy

deepens; division of agriculture \& central

labour involves

specialised roles

transmitted

culturally, including

specialisation in

violence; religious

hierarchy may not

be sufficient to

resolve conflicts $\rightarrow$

possibility of (civil) war

he first towns of a few

hundred people evolve

$\&$ around them larger

area and networks;

these developments

result in chiefdoms

Early civilization

become larger,

towns grow into small

cities up to $10^{4}$

inhabitants; practical

reason and techniques

become more

sophisticated, but

gods/god-kings decide;

individuals may

nonetheless follow their

own "voices" and

desires $\rightarrow$ conflicts $\rightarrow$

laws

City-states ("freedom

from tyrants") are

$\begin{array}{ll}\text { such as money } & \text { from tyrants") are } \\ \text { make abstract } & \text { vulnerable to attacks by }\end{array}$

systems of

exchange and

dominatio

possible;

development of

professional

military-agrarian

empires or may evolve

into an empire; the

vastest empires 50-100

x $10^{6}$ people; voice-

hearing suppressed;

bureaucracy, written slavery is common, but

law and systems of also independent

farming and industry;

empires are led by system-integration

those specialising in across vast spaces may

violence

fail $\rightarrow$ (civil) war 
Also non-human primates can have a primary consciousness. For example, chimpanzees imitate behaviour (Hill, Barton \& Hurtado, 2009, 190) and can learn to use a set of words if taught, but they lack the ability to realize the intentions of others. At the stage of primary consciousness, tools can be used on an ad hoc basis, but not transmitted culturally. "The [...] lives [of those with primary consciousness] are lived entirely in the present, as a series of concrete episodes, and the highest element in their system of memory representation seems to be at the level of event representation" (Donald, 1991, 149). The transition from state 1 to stage 2 does not yet distinguish humans from other primates in any categorical fashion, though becoming increasingly cultural is unique (by cultural I mean transmission of skills and knowledge by means of learning rather than biologically). Culture does not imply spoken language, but requires some intentional communications that can be sustained by a combination of gestures, body language, imitation and sounds. This stage lasted relatively long, especially if compared to later historical times.

It is possible that first elements of spoken language such as intentional calls, modifiers and commands (Jaynes, 2000, 131-3) emerged in some form in archaic hominins, but homo sapiens - in its evolving diversity - turned out to have unprecedented potential in this regard. Based on archaeological records, it seems likely that this phase coincided with the human movement from Africa to Eurasia. Adaptation to new circumstances and encounters with more archaic humans (involving interbreeding with them) seems to have accelerated the development toward stage 4 . New qualities and powers emerged. Larger groups are crucial for the stability of expressions and their meaning, while they were also made possible by the development of the early forms of language. Some human communities seem to have reached this stage about 40,000-50,000 years ago. With concepts (of animals in particular) and some shared rules of language-use, new qualities and causal powers both at the level of human brain and social community emerged. The new powers left some crucial traces for us to observe (stage 4). Language enables concentration on tasks that require time, while at this point also dreams, hallucinations, and powerful images were experienced as real (for first-hand evidence of collective hallucination by contemporary huntergatherers, see Everett, 2008, xv-xvii, 137). These images were replicated for instance in shamanistic cave-paintings, probably for communal purposes and as an indication of access to the other world (cf. the slightly different accounts of Jaynes, 2000, 134-45; Lewis-Williams, 2002, 101-35). As ornaments - possibly carved in tools - images could serve as identity-markers as well. Conditions changed bit by bit during the latest phases of the last Ice Age. Some of the megafauna became locally or totally extinct, in part probably because of human activities. With increased capacity for tool- and clothes-making and cooperation, the new possibilities for adaptation led to slow population growth - enough to prove detrimental to the remaining archaic humans (for example the Neanderthals disappeared from Europe some 40,000 and 37,000 years ago, and in other places soon after).

At stage 5, individuals acquire names while language-rules, including syntax, become more complex and stable (even if they at this stage remain volatile and excessively context-sensitive). Language is made possible by the human capacity to imitate and recognise the intention of others, but once established at some level, it became something that is experienced in part as an external reality. Approaching this stage, humans confuse the individual and group, thus lack a differentiated subjectivity; do not have any mental or metaphorical vocabulary; may lack also concepts for instance for colours and numbers; cannot narratize and thus have no history; are not concerned about the future but rather live through each day as it comes; and do not have gods or religion (cf. Everett, 2008). However, religion emerges in the course of stage 5. Both individual humans and dreamed and hallucinated voices and images start to acquire names, though for a long while these names may change from time to time (an individual may be renamed several times in relation to collective categories based on for example on age). There is little if any differentiation between 
non-living and living nature and the human cultural world. Later, especially when agriculture-based chiefdoms with wider division of labour evolve, particular spirits of nature and various gods might also provide "explanations" as to why things happen (cf. Wright, 2009, 9-69).

At stage 5, some settlements are becoming more permanent (at least for a part of the year) and metagroups larger. Eventually a few metagroups start to experiment with agriculture. The development of language greatly facilitates this experimentation: new names to things increases perception and attention and can lead to accumulation of knowledge (Jaynes, 2000, 138). Domestication (acculturation) of some animals was the first step. Agrovillages form a new energysystem: "the sunlight was converted into food energy by the green fields of crops now 'inside' the cultural system" (Volk, 2017, 135). Agriculture may not have been an obvious choice or a conscious choice at all (Diamond, 1997, 104-13), but some of those communities, which started to pursue this path, eventually expanded - the first of them about 30,000 years after the extinction of Neanderthals. In this process, social differentiation increases and becomes more established. With language/brain experienced as "speaking" to oneself directly - and often giving commands conflicts become increasingly difficult to resolve without a hierarchy. Through a socialevolutionary process, this development resulted invariably in chiefdoms, common in all parts of the world. Those at the top of the religious hierarchy claim privileged access to the world of gods (as already shamans did in some but more limited ways). This ensures social harmony and enables planning, while it also establishes separate classes of people, and involves the possibility of exploitation and discrimination.

Stage 6 corresponds to what Jaynes (2000; see also Kujsten, 2006) calls "bicameral mind". What is noteworthy about both stages 5 and 6 is that volition, planning, and initiative are organized with no reflective consciousness or reflexivity. Jaynes (2000, 117-25) maintains that one side of the brain was in essence giving instructions and commands to the other side. Over time this phenomenon became increasingly enmeshed with social division of labour and hierarchy. What I think is undeniable is that language drastically shapes human brains in terms of its networks of neurons and synapses, but whether this can and should be seen strictly in terms of the left and right hemisphere of the brain is more uncertain (but cf. McGilchrist, 2012). Moreover, while the world of the early civilisations might have been relatively undifferentiated and partly dreamlike and hallucinatory, it would be an exaggeration to see communication at stages 5 or 6 occurring less between people than brain hemispheres (or something equivalent). Probably human-to-human communications (for Jaynes, the left hemisphere) and dream-like, partly hallucinated communications with spirits and gods (right hemisphere, responsible for guiding and planning) appeared side by side. To reiterate, the latter generated a potential coordination problem that became more severe as the community grew. Whenever social or collective action was required, whose voices and visions was to be taken as decisive? We do not know the details of the process that resulted in the steeply hierarchical systems led by a god-king or by a king hearing god(s). What we do know, however, is that only a few communities followed this path to the stage of early civilizations. Those that did ended up in a system exhibiting striking similarity across the world, whether we are talking about Mesopotamia, Egypt, Indus Valley, and China in the Old World or Incas, Aztecs, and Mayas in the New World. Analogous solutions are found at different levels of reality (Volk, 2017, especially 100-11).Thus the early civilizations can be seen as a cultural version of the society of insects:

Like the queen in a termite nest or a beehive, the idols of a bicameral world are the carefully tended centers of social control, with auditory hallucinations instead of pheromones. (Jaynes, 2000, 144) 
Unlike the systems of eusocial animals of bees or ants, however, the early civilizations were cultural and thus liable to rapid changes in terms of skills, division of labour, and means of communication. By this time some people lived in towns of such size that everyone does not know everyone else. Individual social intelligence is partly replaced by more abstract principles of organization, and this leads to the invention of new practices such as book-keeping, which is also the origin of writing. Many features of the early civilizations are difficult to explain without the hypothesis of a bicameral mind (or something equivalent). Why was there at the centre of towns a large building, a house of gods, typically with a human effigy and a table where people could place their offerings? These buildings were bigger than anything else constructed. Sometimes they were taken as dwellings of gods, which only priests could visit. Why did people offer some of their most precious food, valuable artefacts, and in some cases even their own (or other humans') lives as gifts to dead people or gods? How can all this make sense? The bicameral mind hypothesis suggests that people literally heard dead people and gods talk to them. At times, they could hallucinate seeing them as well. At the heyday of this era, the god-king, priests, and supporting administration (with increasingly specialised skills) organised the functioning of the whole from irrigation and harvests to distribution and construction, all intertwined with religious rituals. The top people had not only a privileged access to gods but also to common resources, marking the beginning of latent class conflict. People living in towns could see the tallest building everywhere, the function of which was to remind them of the powerful god-voice that they needed to obey, even against the voices they heard.

The agricultural city-states were very successful in terms of population growth, notwithstanding unintended consequences and occasional catastrophic outcomes such as salination following centuries of irrigation. Stage 6 did not last very long, only a couple of millennia. Such theocracies with strict hierarchies require stability of setting. Mass-movements of people because of population growth, long-distance trade, changing climate, ecological problems, and wars and invasions meant that people left their stability inducing temples and idols. At the same time, writing relayed the commands of gods in a new way, "weaken[ing] the power of auditory hallucinations" (Jaynes, 2006, 91). Book-keeping and writing stabilised meanings, although at first signs, say Đo (this is an arbitrary example), could stand for several different nouns as well as for several different syllables depending on the context. These ambiguities have made it easy for translators to impose modern categories in order to make translations comprehensible to them. "A translator often reads in more than he reads out" (Jaynes, 2000, 177). Be that as it may, the developments in early civilizations led to increasingly abstract categories. Basic arithmetic followed book-keeping. Soon an abstract concept of value that started to constitute practices of justice and exchange. A case in point is the Mesopotamian shekel that was nominally equivalent to a specific weight of barley. In the Code of Hammurabi (c. 1750), it was used to fix equivalences by divine decree in the context of compensation for wrongdoings and exchange of goods. Soon after this, letters of officials became commonplace and were increasingly used to administer large areas, including through "mythodiplomacy" (Der Derian, 1987, chp 4) with neighbouring city-states that had competing gods and related claims. The hallucinations of shamans/priests/god-kings were gradually replaced by written texts, though for centuries these texts still reflected the contents of the bicameral mind. At around this time some of the early civilizations such as Assyria became increasingly violent. In the absence of auditory hallucinations, cruelty, and oppression become the ways in which a ruler imposes his rule upon his numerous subjects.

Many of the elements of reflective consciousness and early reflexivity evolved gradually during stage 6, including the metaphorical mind-space, the analogy "I", and narratisation. These enabled, among other things, new levels of long-term planning resulting e.g. in walls around cities. The transition to a world of reflectively conscious agency took a few more centuries. Step by step, the 
increasingly counterproductive voice-hearing was suppressed. The beginning of Karl Jaspers's (1953) axial age dates back to 800 BCE. From the axial age onwards, the most advanced religions revolve around texts that are revealed to humanity through a guru, prophet or a "son of god" that can still hear god, but for the rest of people gods remain mostly silent. Thucydides (c.460 BCE c. 400 BCE) managed to write a story of the Peloponnesian wars where gods played no role except through human beliefs, even though for Thucydides the fall of Athens was also a moral story where it received an almost-cosmic punishment for its ethical decline (Patomäki, 2002, chp 7). Institutions, such as money, began to take functions that are familiar to people living in a capitalist market society. City-states continue to operate mostly through oral communication, but they also write constitutions where their key political and judicial institutions are defined. Free men can now condemn tyrannies and praise freedom. Philosophers such as Plato can imagine alternative ways of organising political communities (utopias). However, small city-states are vulnerable to attacks by military-agrarian empires or may evolve into such an empire. The vastest empires (Rome, Handynasty China) comprised at their height some 50-100 million people and 5-6 million $\mathrm{km}^{2}$. While slavery was common, also independent farming and industry were important. System-integration across vast spaces can easily fail - partly because of unmanageable distances (given also the available means of communication and transportation) and external invasions; partly because the principles of rule were contested (including rules of succession). Various mixes of disintegration and invasions could prompt a civil war, occasionally spelling end to a system of rule, dynasty or an empire as a whole. Some empires were rebuilt many times.

The development through stages is neither linear nor uniform across contexts. Partial regress is possible and communities may stick to their practices even when they interact closely with communities at higher stages. Once several stages are in place, all kinds of combined formations become possible, in which features of a lower stage are merged with those of a later stage of development. Knowledge, skills, artefacts, gods, aspects of language, organising principles and so on can easily diffuse from one place and community to another. Hunter-gatherers may continue with their life-style, at least for a while, even after they have acquired industrially produced goods (clothes, tools etc.) and learnt to speak colonial languages. This makes it especially difficult to identify original stages by observing recent or current practices and systems. Moreover, the combined formations may exhibit contradictions and all kinds of peculiarities. They may deviate so much from the rule and effect such an upheaval as to make the less advanced more powerful for instance in military terms, though later they may adopt elements of the more advanced system (think about the role of Mongols in world history). Some Marxians use the phrase "uneven and combined development" to describe similar phenomena in the contemporary context (Rosenberg, 2016). The idea is generalizable beyond $19^{\text {th }}$ or $20^{\text {th }}$ century capitalism.

The point is that Searlean and critical realist social ontologies presuppose reflective consciousness, reflexivity, and agency (stage 7 or beyond). It is true that in some passages, Searle (1995, e.g. 7) seems to assume that primacy consciousness (stage 1) would suffice for the establishment of institutional facts, but at other times institutional facts are essentially connected to constitutive rules (' $\mathrm{X}$ counts as $\mathrm{Y}$ in context C'), self-referential concepts, and performative utterrances. Searle (1995, 32) writes for instance that "logically speaking, the statement 'A certain type of substance, $x$, is money' implies an indefinite inclusive disjunction of the form ' $\mathrm{x}$ is used as money or $\mathrm{x}$ is regarded as money or $\mathrm{x}$ is believed to be money, etc."'. For money to exist, people (analogy "I") must have beliefs about other people's beliefs and practices, which they can relate to themselves (metaphor "me"; cf. Lawson, 2019, chps 5-6). Soon Searle explains further that an institutional fact cannot exist in isolation but only in a wider context. Thus for example money presupposes a system of exchanging goods and services for money. "But in order that it can have a system of exchange, it must have a system of property and property ownership." (Ibid., 35) Something like that started to 
exist during the Axial Age in some of the main hubs of the Old World, while for large parts of humanity institutional facts in this sense did not yet exist.

In a similar manner, also Bhaskar's Transformational Model of Social Activity (TMSA) refers to geo-historically specific elements. According to TMSA, society is both the ever present condition (material cause) and the continually reproduced outcome of human agency. People in their conscious activity unconsciously and sometimes consciously reproduce (and occasionally transform) the structures governing their substantive activities of production. The purpose of social ontology and theory is to show that human activities can be reflexive and that actors can aim at emancipation from unwanted, unneeded and unnecessary sources of determination. The genesis of human actions lie in the reasons, intentions and plans of people. This model presupposes some particular and rather advanced properties of human agency (cf. Archer, 2000):

Human action is characterized by the striking phenomenon of intentionality. This seems to depend upon the feature that persons are material things with a degree of neurophysiological complexity which enables them not just, like the other higher-order animals, to initiate changes in a purposeful way, to monitor and control their performances, but to monitor the monitoring of these performances and to be capable of a commentary upon them. This capacity for second-order monitoring also makes possible a retrospective commentary upon actions, which gives a person's account of his or her own behaviour a special status, which is acknowledged in the best practice of all the psychological sciences. (Bhaskar, 1998, 38)

Compare this to the prevailing mentality in the ancient world that was in the process of reaching stage 7. We may recognise the ancient mentality as something familiar, but whether those societies really fulfil the criteria of Searlean or CR social ontologies is less evident. For example reflexivity, self-referential concepts, and second-order monitoring of activities may be more characteristic of $20^{\text {th }}$ or $21^{\text {st }}$ century world society than classical antiquity. For all the wisdom of Plato and Aristotle or Cicero and Lucretius - and similar figures in the Indus valley or China - most people in the ancient societies remained illiterate. For example, it is possible that Plato's hero Socrates could not read - at least he never wrote anything. What is more, Socrates seems to have exhibited features of bicameralism. He heard voices and was guided by them. Socrates's daimon was an external voice or command that would cause him to stop in his tracks. (For example Critchley, 2008, xvi) In his last days Socrates announced that "I am that gadfly which God has attached to the state"; and that "I am given to you by God" (Plato, 1999). As we know, Socrates was eventually indicted for failing to honour both Athenian democracy and its gods, and was condemned to death.

Literate ancient philosophers might have been less bicameral but nonetheless tended to reify social distinctions and institutions (to use concepts of critical social sciences). Archer (2010,4) cites Plato's Theaetetus as the first ever characterisation of reflexivity, meaning "the conversation which the soul holds with herself in considering of anything". However, Plato's or Aristotle's inner conversation does not mean a hypothetical attitude to the conventions or structures of society. For Aristotle "natural slaves", women and lower-status men are essentially meant to serve the purpose of the good life of the aristocracy and free men. The outside world forms concentric circles of increasing barbarity. The further you go, the more barbarity you should expect to find. Like the apparent rotation of planets and stars - including the sun - around the Earth, this kind of ethnocentrism is essentially an illusion of perspective stemming from being familiar with things that are close; from social practices that are structured to serve the purpose of the few and their sense of community; and from asymmetrical relations of power. It is noteworthy that Aristotle did not support democracy even among free male citizens, but rather argued for a compromise between what he called polity and aristocracy (aristoi means literally 'best persons'). For Aristotle, the true 
centre consists only of the central observer and of the few that are equal to him. In China, the Confucians reached similar conclusions regarding everyone's given, rightful place in society. The Confucians also entertained related ideas of governance by virtue and practical reason rather than by force, and of applying the principles of freedom and tolerance only to the privileged few (for details and references, Patomäki, 2010, 184-8; for an explanation of why Aristotle's theories did not allow him to look critically into his own conceptual metaphors and cognitive unconsciousness, see Lakoff and Johnson, 1999, 373-90).

Searlean and CR social ontologies focus on specific geo-historical formations from a rather limited perspective, largely ignoring their concrete historical emergence and development, diversity, and future possibilities. What Searle and critical realists describe is a literate and secularised world of humans with reflective consciousness and capacity for evaluating their own actions as well as social relations, rules, and principles (even when most of their everyday practices are based on unconscious rule-following). For one thing, this makes it difficult to study how reflective consciousness is dependent on earlier layers and how the earlier layers - and the analogues and metaphors constituting reflective consciousness - can be causally efficacious with regard to current actions, practices and institutions, while also being moulded by them. For example, at stage 7 , bodily things such as breathe, blood, lungs, heart and head were turned into metaphors and started to denote psyche, spirit, soul, life, emotions, intelligence and self. The repertoire of simple affects that we share with other mammals was transformed into complex human emotions: fear became anxiety, shame was translated into guilt and mating was turned into sex. These and many other conscious emotions were made possible by analogues and metaphors, which have been subsequently used to debate and theorise justice, goodness, morality, emotions, and the meaning of human existence. Or to give another example, many of the features of the "bicameral world" remain efficacious in the $21^{\text {st }}$ century globalised world. With the breakdown of the bicameral mind, the world of gods and their brain-induced voices receded and aspects of this "external" world were transformed into elements of the Background of social activities (to use Searle's terminology; background capabilities have evolved through stages 1-7 and beyond). Yet in the $21^{\text {st }}$ century many people continue to hear voices, religions are resurgent, and authoritarian leaders talking about god are widely followed. Religions can also be anti-authoritarian and secular ideologies may be functionally equivalent and structurally isomorphic with religions. Meanings change with context and new meanings emerge, yet their explanation may continue to require reference to earlier layers (these remarks do not imply the denial of relevance of fundamental existential and theological questions). Reflective consciousness and language are causally efficacious, but built on top of many layers. It is not only that the reflectively conscious self is context-dependent, but its potentially expanding powers are limited given the complexities of human constitution.

Social ontology should reflect the fact that human beings, social relations, and social wholes exist in diverse and evolving ways. Stage 7, or any stage beyond that, is merely a stage, not the end of history, and can be combined with other stages and developments. "It would be wrong to think that whatever the neurology of consciousness now may be, it is set for all time" (Jaynes, 2000, 125). The same holds true for forms of agency and such (metaphorical) concepts of social theory as "status functions", "reproduction", "structures", "institutions", or "positioning". Their relevance is contingent and their meanings are shifting also in relation to the prevalence of different sociohistorical formations. Our reflexivity and relationship to particular institutions such as money; our conceptions of self, space, and time; and the size and complexity of human organizations are all liable to change. Change and emergence take time, and certain categories may endure through a historical longue durée, but human/personal/social being is processual and historical and should be theorised as such. 


\title{
Endnotes
}

\begin{abstract}
${ }^{1}$ The old versions of English, French, or German evolved during the so called Middle Ages, but here Searle is referring to the modern versions of these languages (of course, languages such as English have evolved within the "modern" period as well, as any reader of Shakespeare or Hobbes can testify). Searle's characterisation of "full-blown language" seems Chomskyan, suggesting a universal inner generative grammar. It conflates language as a conceptual system and social imaginary (see Bourdieu, 1990, pp. 54-55) with actually spoken and written languages such as English, French, or German. The same conceptual system may be shared across multiple "national" languages; while a number of conceptual systems and social imaginaries may co-exist within any "national" or concrete language (problems of understanding are not unique to inter-language translations). Language as a system of meaning consists of historical concepts, narrative and visual prototypes, metaphors, conceptual blendings and framings (for a discussion on national and global imaginaries along these lines, see Patomäki and Steger, 2010). As I argue later in the paper, complex systems of meanings have existed only for a relatively short time, that is since the emergence of metaphorical language.
\end{abstract}

${ }^{2}$ Here I am conflating different CR versions of emergence, although for some purposes these differences do matter. Bhaskar (2010, p. 54) defines emergence "as the relationship between two terms such that one diachronically, or perhaps synchronically, arises out of the other, but is capable of reacting back on the first and is in any event causally and taxonomically irreducible to it". For Bhaskar, fundamental levels are emergent, but also many relational things within layers are emergent (he is not very specific about the latter but stresses that "emergence is a widespread phenomenon" (p. 78) and connects it with the concept of totality that is ubiquitous also in society and argues that in society especially contradictions can result in emergence (p. 165)). Lawson (2019, especially chaps. 2 and 7) discusses emergence in more detail and seems more cautious. While Lawson too defends a "strong" form of emergence and argues emergence to be ubiquitous also within levels, Lawson rejects the possibility of "top-down" causation (even though he also maintains that the higher level entities are both causally and ontologically irreducible to the lower level realities). Lawson (2019, pp. 214-) conceptualises emergence within the social layer in terms of "certain powers of coordinated interactions" and denies that emergent whole can have a causal impact on its parts. Specifically, his argument is that totalities such as "crowd" or "language" do not exert efficient causation on their parts, even though the organising relational structure of the whole shapes the behaviour of its parts in terms of formal causation. However, not only does this argument take the individual human actors as given (rather than something enabled and constituted by social structures and shaped by social experiences and circumstances), but I also do not see any reason to restrict causation to Aristotle's efficient causes (material and formal causes can be necessary or non-redundant parts of causal complexes that generate - also in the sense of efficient causation - the outcomes that we want to explain). Downward causation is an essential part of my argument: I-intentionality and individuality are effects of our collective history, as are many characteristics and powers of those individuals once formed (also and especially through their social positioning). Here I am in agreement with Jacques Derrida's (1997) "science of grammatology": our self-conscious existence is possible only because of complex society and language, or to use his terminology, because of "archwriting".

3 "Appendix: on the stages of development from the era of archaic humans to the axial age" is too long to be published as a part of this article, but can be found permanently at https://zenodo.org/record/3984609\#.XzYp6JCP4aG (DOI: 10.5281/zenodo.3984609); and for the time being also at https://patomaki.fi/wp-content/uploads/2020/08/APPENDIXSeven-stages-FINAL-1.docx.

${ }^{4}$ See Appendix [note 3]. Jaynes provides many types of evidence for his claims. (1) At one level, he is concerned with archaeological evidence: given the absence or emergence of something in a given moment, what is the most plausible and powerful explanation for that absence or emergence? This applies also to the hypothesis about a 'bicameral' mind that prevailed in the early civilizations. It might be objected that Jaynes's bicameral mind of internal processing that is experienced as other or external is possible but it does not seem necessary for the practices it is used to explain. However, necessity is a too strong a claim; what suffices is that the explanation is plausible and powerful. (2) At the second level, Jaynes relies also on the available textual evidence about the period of transition from the bicameral era to the era of reflective consciousness. Thus he provides a radically new (fresh still in the 2020s) and yet plausible reading of Iliad and Odyssey and the Old Testament. Iliad and the older parts of the Old Testament depict an oral world without reflective consciousness, whereas Odysseus and the later parts of the Old Testament are more familiar to us. "Iliadic man did not have subjectivity as do we; he had no awareness of his awareness of the world, no internal mind-space to introspect upon. In distinction to our own subjective conscious minds, we can call the mentality of the Myceneans a bicameral mind. Volition, planning, initiative is organized with no consciousness whatever and then 'told' to the individual in his familiar language, sometimes with the visual aura of a familiar friend or authority figure or 'god', or sometimes as a voice alone. The individual obeyed these hallucinated voices because he could not 'see' what to do by himself. The evidence for the existence of such a mentality as I have just proposed is not meant to rest solely on the Iliad. It is rather that the Iliad suggests the hypothesis that in later chapters I shall attempt to prove or refute by 
examining the remains of other civilizations of antiquity.” (Jaynes, 2000, p. 75) (3) At the third level, Jaynes uses evidence drawn from psychiatry and brain studies. Even today a large part of the population has experiences about hallucinations (either voices or visual or both). Moreover, Jaynes interprets some symptoms associated with schizophrenia as similar to the hallucinations of the ancient world and as remnants of the bicameral mind in the contemporary world. Jaynes's account of the evolving brain structure may be dated, but it is beyond my competence to assess whether that would affect his overall argument. As far as I can see, his account remains plausible.

${ }^{5}$ Note 3.

${ }^{6}$ Personally, I first learnt about this in Searle's (in)famous review on Jonathan Culler's book on deconstruction. In a footnote Searle (1983, p. 75) suggests that perhaps Derrida and Culler are not aware that the ancient Greeks read aloud? Louis H. Mackey (1985) responded on Derrida's and Culler's behalf by writing "it is unthinkable (by anyone not out to get them) that either Derrida or Culler is bereft of this commonplace". The story of how reading has evolved can be found in many books (moreover, numerous short texts can be easily found easily by googling). What I cannot explore properly in this article - though I do suggest as much in the main text - is Saenger's (1997) extremely valuable and interesting suggestion that asocial reading helped to enlarge the space for inner conversation by facilitating introspection. This further development made criticism of the government, religion, and various authorities easier, while also enabling the use of irony and cynicism. This probably paved the way for the $18^{\text {th }}$ century Enlightenment.

${ }^{7}$ See appendix [note 3] for details; and note 4 for the types of evidence provided by Jaynes himself.

${ }^{8}$ Searle's rather neoclassical account of money indicates not only that institutions evolve but also that for a long time money included elements that do not fully accord with his notion of status functions. Although we do know that the concept and functions of money have changed, there is no consensus about what money is. For instance, Geoffrey Ingham (2004) discusses also non-neoclassical theories (including state and credit theories) of money in light of historical developments; while Lawson (2019, chap. 6) criticises the credit theory and offers his positioning theory of money in its stead, illustrating it with several historical examples. The essence of money remains contested and these contestations are part of the political history of money and related institutions such as banks and central bank (the social world is, in its essence, often vague, incomplete and ambiguous, involving ambivalence and contradiction; see Patomäki, 1991, pp. 225-7). Money, markets and capitalist market society are essentially connected. We may also go deeper and ask 'what is capitalist market society?'. Geoffrey Hodgson (2015) argues that the essence of "capitalism" can only be captured by means of nested definitions with different degrees of generality. Markets, profits, private property and wage labour lie at the heart of capitalism, but "a large number of different types of subsystem could be combined in principle with the definitional core, a large variety of different capitalisms are possible" (p. 51). Even those features that are part of the definitional core have been changing, with new layers of (micro-)emergence. For instance, "there is no 'the market,' there are only markets, with many dissimilar, even contradictory, traits" (McDermott, 2011, p. 17). These traits have evolved historically. For example, think about a credit-financed purchase of an automobile involving various authorities and insurance companies and the various costs that incur over time. This "market" is quite different from buying a piece of clothing with metallic coins in the market square of a typical small 18th century town in Europe.

\section{$\underline{\text { References }}$}

Archer, M. (1995). Realist social theory: the morphogenetic approach. Cambridge: Cambridge University Press.

Archer, M. (2000). Being human. The problem of agency. Cambridge: Cambridge University Press.

Archer, M. (2010). Introduction: the reflexive re-turn. In M.Archer (ed.) Conversations About Reflexivity (pp. 1-13). London \& New York: Routledge.

Baggio, G. (2020). Emergence, time and sociality: comparing conceptions of process ontology. Cambridge Journal of Economics, published online in June 2020. doi:10.1093/cje/beaa019

Bhaskar, R. (2008a). A realist theory of science. With a new introduction. London and New York: Routledge. [Originally published in 1975]. 
Bhaskar, R. (1998). The possibility of naturalism. A philosophical critique of contemporary human sciences (3rd edition). London and New York: Routledge. [Originally published in 1979].

Bhaskar, R. (2009). Scientific realism and human emancipation. London \& New York: Routledge. [Originally published in 1986].

Bhaskar, R. (2008b). Dialectic. The pulse of freedom. With a new introduction. London \& New York: Routledge. [Originally published in 1993].

Bhaskar, R. (2010). Plato etc. The problems of philosophy and their resolution. London \& New York: Routledge. [Originally published in 1994].

Bourdieu, P. (1990). The logic of practice. Stanford: Stanford University Press.

Bourdieu, P. \& Wacquant, L. (1999). On the cunning of imperialist reason. Theory, Culture \& Society, 16, 41-58. doi: 10.1177/026327699016001003.

Braudel, F. (1980). On history. Transl. S.Matthews. The University of Chicago Press: Chicago.

Camilleri, J. A. \& Falk, J. (2009). Worlds in transition. Evolving governance across a stressed planet. Cheltenham: Edward Elgar.

Cangelosi, A. (2005). The emergence of language: neural and adaptive agent models. Connection Science, $17,185-90$.

Clayton, P. (2013). On the plurality of complexity-producing mechanisms. In C. Lineweaver (ed.)

Complexity and the arrow of time. Cambridge University Books: Cambridge, pp.332-51.

Critchtley, S. (2008). The book of dead philosophers. Melbourne University Press: Melbourne.

Derrida, J. (1997). Of grammatology. Transl. by G. Spivak; corrected edition. Baltimore and London: Johns Hopkins University Press. [Originally published in 1967].

Derrida, J. (1988). Limited inc. Trans. by A. Bass and S. Weber. Evanston IL: Northwestern University Press.

Diamond, J. (1999). Guns, germs, and steel. The fates of human societies. New York: W.W. Norton.

Donald, M. (1991). Origins of the modern mind. Three stages in the evolution of culture and cognition. Harvard University Press: Cambridge, MA.

Edelman, G. M. (1992). Bright air, brilliant fire. On the matter of the mind. BasicBooks (division of HarperCollins): New York.

Everett, D. (2008). Don't sleep, there are snakes. Life and language in the amazonian jungle. Profile Books: London.

Habermas, J. (1979). Communication and the evolution of society. Trans. T. McCarthy. Boston: Beacon Press.

Habermas, J. (1990). Justice and solidarity: on the discussions concerning "stage 6". In M.Kelly (ed.) Hermeneutics and Critical Theory in Ethics and Politics (pp. 32-52). Cambridge, MA: The MIT Press. 
Hauser, M. D., Chomsky, N. \& Fitch, W. T. (2002). The faculty of language: what is it, who has it, and how did it evolve?. Science, 298, 1569-79. doi: 10.1126/science.298.5598.1569

Henshilwood, C. \& Marean, C. (2003). The origin of modern human behavior. Critique of the models and their test implications. Current Anthropology, 44, 627-51. doi: 10.1086/377665

Hill, K., Barton, M. \& Hurtado, A. M. (2009). The emergence of human uniqueness: characters underlying behavioral modernity. Evolutionary Anthropology, 18, 187-200. doi: https://doi.org/10.1002/evan.20224

Hodgson, G. (2015). Conceptualizing capitalism. Institutions, evolutions, future. Chicago and London: The University of Chicago Press.

Ingham, G. (2004). Nature of money: new directions in political economy. Cambridge: Polity Press.

Jaspers, K. (1953). The origin and goal of history. Trans. by M. Bullock. London: Routledge \& Kegan Paul.

Jaynes, J. (2000). The origin of consciousness in the breakdown of the bicameral mind. Boston, MA:

Houghton Mifflin.

Jaynes, J. (2006). Verbal hallucinations and pre-conscious mentality. In M.Kujsten (ed.) Reflections on the dawn of consciousness. Julian Jaynes's bicameral mind theory revisited. Julian Jaynes Society: Henderson, NV, pp.75-94. doi: https://doi.org/10.1007/978-1-4613-9028-2_11

Klein, R. G. (1995). Anatomy, behavior, and modern human origins. Journal of World Prehistory, 9, 16798. doi: https://doi.org/10.1007/BF02221838

Kujsten, M. (ed.) (2006). Reflections on the dawn of consciousness. Julian Jaynes's bicameral mind theory revisited. Julian Jaynes Society: Henderson, NV.

Kohlberg, L. (1971). From is to ought: How to commit the naturalistic fallacy and get away with it in the study of moral development. In T.Mischel (ed.) Cognitive Development and Epistemology (pp. 151-235). New York: Academic Press.

Kohlberg, L. (1973). The claim to moral adequacy of a highest stage of moral judgment. Journal of Philosophy, 70, 630-46. doi: 10.2307/2025030

Kohlberg, L. (1981). The philosophy of moral development. Moral stages and the idea of justice. Essays on moral development volume 1. San Francisco: Harper \& Row.

Kujsten, M. (2006). Introduction. In M.Kujsten (ed.) Reflections on the dawn of consciousness. Julian Jaynes's bicameral mind theory revisited (pp. 1-10). Julian Jaynes Society: Henderson, NV.

Lakoff, G. \& Johnson M. (1999). Philosophy in the flesh: the embodied mind and its challenge to western thought. New York: Basic Books.

Lawson, T. (1997). Economics \& reality. London and New York: Routledge.

Lawson, T. (2016a). Comparing conceptions of social ontology: emergent social entities and/or institutional facts?. Journal for the Theory of Social Behaviour, 46, 359-99. doi: 10.1111/jtsb.12126

Lawson, T. (2016b). Some critical issues in social ontology: reply to John Searle. Journal for the Theory of Social Behaviour, 46, 426-37. doi:10.1111/jtsb.12129

Lawson, T. (2019). The nature of social reality: issues in social ontology. London and New York: Routledge. 
Lewis-Williams, D. (2002). The mind in the cave. Consciousness and the origins of art. Thames \& Hudson: London.

Little, D. (2016). New directions in the philosophy of social science. London \& New York: Rowman \& Littlefield.

Mackey, L. (1984). An exchange on deconstruction. The New York Review of Books, February 2 Issue, pp. 47-8. Available at https://www.nybooks.com/articles/1984/02/02/an-exchange-ondeconstruction/.

Macwhinney, B. (2005). The emergence of linguistic form in time. Connection Science, 17, 191-211. doi: $10.1080 / 09540090500177687$

McGilchrist, I. (2012). The master and his emissary. The divided brain and the making of the western world. Yale University Press: New Haven, CT.

McDermott, J. F. M. (2011). Chamberlin and Robinson: their realism revisited and revised. Journal of Post Keynesian Economics, 34, 159-178.

McNeil, J. R. \& McNeill, W. H. (2003). The human web: a bird's-eye view of world history. New York: W.W. Norton.

Mill, J. S. (1882). A system of logic, ratiocinative and inductive. $8^{\text {th }}$ edition. New York: Harper $\&$ Brothers. Available at https://www.gutenberg.org/ebooks/27942.

O'Connor, T \& Wong, H. Y. (2015). Emergent properties. The Stanford encyclopedia of philosophy. Edward N. Zalta (ed.). Retrieved from https://plato.stanford.edu/archives/sum2015/entries/properties-emergent/.

Patomäki, H. (1991). Concepts of "action", "structure" and "power" in "critical social realism": a positive and reconstructive critique. Journal for the Theory of Social Behaviour 21, 221-250. doi: 10.1111/j.14685914.1991.tb00521.x

Patomäki, H. (2002). After international relations. Critical realism and the (re)construction of world politics. Routledge: London and New York.

Patomäki, H. (2010). Cosmological sources of critical cosmopolitanism. Review of International Studies, 36, 81-200. doi:10.1017/S0260210510001063

Patomäki, H. (2011). On the complexities of time and temporality: implications for world history and global futures. Australian Journal of Politics and History, 57, 339-352. doi: 10.1111/j.1467-8497.2011.01600.x

Patomäki, H. (2019). The promises of critical realism in the 2020s and beyond. Teoria Polityki, 3, 189-200. doi: 10.4467/25440845TP.19.010.10293

Patomäki, H. (2020). Scientific realism. In J-F.Morin, C.Olsson \& E.Atikcan (eds.) Key Concepts in Research Methods. Oxford University Press: Oxford, forthcoming in early 2020.

Patomäki, H. \& Steger, M. B. (2010). Social imaginaries and big history: towards a new planetary consciousness?. Futures, 42, 1056-63. doi: 10.1016/j.futures.2010.08.004

Plato (2009). Apology [also known as "The Death of Socrates"]. Transl. by B.Jowett, Project Gutenberg ebook. Retrieved from http://www.gutenberg.org/1/6/5/1656/. 
Rosenberg, J. (2016). International relations in the prison of political science. International Relations, 30, 127-153. doi: https://doi.org/10.1177/0047117816644662

Polanyi, K. (1957). The great transformation. The political and economic origins of our time. Boston, MA: Beacon Press. [Originally published in 1944].

Politis, V. (2004). Aristotle and the metaphysics. London \& New York: Routledge.

Rawls, J. (1971). A theory of justice. The original edition. Cambridge, MA: The Belknap Press of Harvard University Press.

Rawls, J. (1985). Justice as fairness: political not metaphysical. Philosophy \& Public Affairs 14, 225-226.

Rescher, N. (1996). Process metaphysics. An introduction to process philosophy. New York: State University of New York Press.

Saenger, P. (1997). Space between words: the origins of silent reading. Stanford, CA: Stanford University Press.

Searle, J. (1983). The word turned upside down. The New York Review of Books, October 27 Issue, pp. 74-79. Available at https://www.nybooks.com/articles/1983/10/27/the-word-turnedupside-down/

Searle, J. (1995). The construction of social reality. New York: The Free Press.

Searle, J. (2010). Making the social world. Oxford: Oxford University Press.

Searle, J. (2016). The limits of emergence: reply to Tony Lawson. Journal for the Theory of Social Behaviour 46, 400-12. doi: 10.1111/jtsb.12125

Smith, B. \& Searle, J. (2003). The construction of social reality. An exchange. American Journal of Economics and Sociology, 62, 285-309.

Tomasello, M. (2008). Origins of human communication. The MIT Press: Cambridge, MA.

Unger, R. M. (1997). Politics: the central texts: theory against fate. Ed. and intro. by Zhiyuan Cui. London: Verso.

Volk, T. (2017). Quarks to culture. How we came to be. New York: Columbia University Press.

Westaway, M. (2019). The first hominin fleet. Nature Ecology \& Evolution, 3, 999-1000. doi: $10.1038 / \mathrm{s} 41559-019-0928-9$

Williams, G. (2011). What is it like to be nonconscious? A defense of Julian Jaynes. Phenomenology and the Cognitive Sciences 10, 217-39. doi: 10.1007/s11097-010-9181-z

Wright, R. (2009). The evolution of god. Little, Brown and Company: New York. 